This item was submitted to Loughborough's Research Repository by the author.

Items in Figshare are protected by copyright, with all rights reserved, unless otherwise indicated.

\title{
Development and validation of a building design waste reduction model
}

PLEASE CITE THE PUBLISHED VERSION

http://dx.doi.org/10.1016/j.wasman.2016.05.026

\section{PUBLISHER}

(c) Elsevier

VERSION

AM (Accepted Manuscript)

\section{PUBLISHER STATEMENT}

This work is made available according to the conditions of the Creative Commons Attribution-NonCommercialNoDerivatives 4.0 International (CC BY-NC-ND 4.0) licence. Full details of this licence are available at: https://creativecommons.org/licenses/by-nc-nd/4.0/

\section{LICENCE}

CC BY-NC-ND 4.0

\section{REPOSITORY RECORD}

Llatas, C., and Mohamed Osmani. 2016. "Development and Validation of a Building Design Waste Reduction Model". Loughborough University. https://hdl.handle.net/2134/21796. 


\title{
Development and validation of a building design waste reduction model
}

\author{
C. Llatas ${ }^{\mathbf{a}}$ and M. Osmani ${ }^{\mathbf{b}}$ \\ ${ }^{\text {a }}$ Departamento de Construcciones Arquitectónicas I, Universidad de Sevilla, ETS de \\ Arquitectura, IUACC, Avda. Reina Mercedes 2, 41012 Sevilla, Spain. \\ ${ }^{\mathbf{b}}$ School of Civil and Building Engineering, Loughborough University, Loughborough, \\ Leicestershire LE11 3TU, United Kingdom.
}

\begin{abstract}
Reduction in construction waste is a pressing need in many countries The design of building elements is considered a pivotal process to achieve waste reduction at source, which enables an informed prediction of their wastage reduction levels. However the lack of quantitative methods linking design strategies to waste reduction hinders designing out waste practice in building projects. Therefore, this paper addresses this knowledge gap through the design and validation of a Building Design Waste Reduction Strategies (Waste ReSt) model that aims to investigate the relationships between design variables and their impact on onsite waste reduction. The Waste ReSt model was validated in a real-world case study involving 20 residential buildings in Spain. The validation process comprises three stages. Firstly, design waste causes were analyzed. Secondly, design strategies were applied leading to several alternative low waste building elements. Finally, their potential source reduction levels were quantified and discussed within the context of the literature. The Waste ReSt model could serve as an instrumental tool to simulate designing out strategies in building projects. The knowledge provided by the model could help project stakeholders to better understand the correlation between the design process and waste sources and subsequently implement design practices for low-waste buildings.
\end{abstract}

Keywords: Building design waste reduction model; design waste reduction strategies; design waste reduction level quantification; design waste reduction assessment. 


\section{Introduction}

The large amounts of waste generated by the construction industry represent a growing problem that requires effective planning, management and monitoring in many countries. The construction industry in the EU-28, is the greatest producer of waste among all European industries, being responsible for $34 \%$ of total waste generation (Eurostat, 2013). Construction activities also represent a significant source of toxic substances accounting for $22 \%$ of all EU hazardous waste (Eurostat, 2010). Additionally, construction and demolition waste (CDW) recovery and backfilling rates in some EU Member states such Cyprus, Greece and Finland are as low as $10 \%$ (European Commission, 2011) of the overall landfilled waste. Furthermore, CDW production has adverse effects on the environment and involves a significant project budget increase due to the loss of tonnage of materials being sent to landfill in addition to labor double handling, transportation and landfill costs. In the UK, for example, where CDW equates to three times the combined waste produced by all households (Defra, 2007), their disposal costs the industry around $£ 1$ billion per year (WRAP, 2008). Consequently, over several decades, an ever-increasing social awareness has prompted governments to develop environmental policies to curb CDW. Particularly, CDW prevention and reduction at source has become a priority in the EU waste management hierarchy (European Commission, 2008). However, the latest European statistics revealed that while the generation of some waste streams, such as in the household sector, remained constant and others fell, namely manufacturing waste which decreased by 26\% between 2004 and 2012; the levels of CDW grew at a rapid pace reaching 45\% increase in the same period (Eurostat, 2015). Therefore, governmental-driven legislative and regulatory measures are proving ineffective as they have failed to reduce CDW generation resulting in a lack of quantitative waste reduction targeting and benchmarking data that would help designers and contractors minimize waste in their construction projects.

There is consensus in the literature that to prevent or minimize construction waste $(\mathrm{CW})$, it is necessary to consider its reduction during design (Osmani, et al, 2008; Innes, 2004; Coventry and Guthrie, 1998; Bossink and Brouwers, 1996). Nevertheless, the bulk of international academic research endeavors over the past decade have been focused on methods and strategies to manage $\mathrm{CW}$ that has already been generated if compared with design waste (DW) 
reduction research, which is "limited and piecemeal" (Osmani, 2013). As such, Lu and Yuan (2010) acknowledged there is a pressing need to investigate CW issues in project design. Furthermore, approaches of existing-methods on DW reduction are largely unfitting because "they do not specifically identify waste-stream components in relation to their occurrence during the architectural design" (Osmani et al., 2008). Therefore, this paper aims to develop and validate a model for Building Design Waste Reduction Strategies (Waste ReSt) that accentuates and assesses the relationships between design variables and their impact on onsite waste reduction using a structured, traceable and quantitative approach. A case study was conducted to apply the proposed model to 20 Housing buildings in Andalusia in Spain. It is expected that the identified variables associated with DW reduction strategies and their interrelationships could assist project stakeholders in understanding and addressing DW sources in building projects.

Within the context of this paper 'design waste (DW)' is defined as construction waste that could be avoided during the design stage; waste 'sources' are associated with DW generation provenance in the building site (e.g. damaged materials and excavated soil); waste 'parameters' refer to variables considered in the design stage that affect the DW sources; 'building element' is a key component of a building (e.g. beam, wall and door); and 'building system 'represents a group of building elements that are interrelated and coordinated among themselves through the project (e.g. structure, masonry, carpentry).

\section{A review of design waste literature}

\subsection{Design waste causes}

Several studies identified design as a key stage of a project life cycle to identify and adopt specific waste minimization actions that could be implemented throughout the construction phase. Innes (2004) estimated that $33 \%$ of on-site waste is due to architects' failure to implement waste reduction measures during design stages. Uninformed design decisions such as inadequate dimensional coordination during the design stage tend to generate off-cuts, which were identified as a major waste cause (Bossink and Brouwers, 1996). Similarly, 
Ekanayake and Ofori (2000) rated lack of information on drawings, complexity of detailing, selection of low-quality materials and lack of familiarity of alternative products as the most significant causes of waste. Furthermore, Chandrakanthi et al. (2002) attributed DW causes to lack of knowledge about construction techniques during design activities, alternative products and standard sizes available in the market.

Several research studies identified last minute design changes, which result in rework and partial demolition, as a significant DW cause. This was attributed to various design related inefficiencies, including errors in specifications and contract documents (Poon et al., 2004; Poon and Jaillon, 2002); last minute client requirements (Poon et al., 2004; Poon and Jaillon, 2002; Coventry et al., 2001); and the complexity of detailing drawings or changes in the type or quantity of building materials required at later stages (Osmani, 2013). A recent study categorized causes of design errors into three types: illogical design such as clashes between different building elements as well as drafting errors; discrepancies between drawings; and missing items (Won et al., 2016). These causes could be addressed through an integrated building design that can avoid design changes, thereby reducing onsite construction waste generation (Cheng et al., 2015).

Additionally, there is general agreement in the literature that poor communication between project stakeholders' leading to mistakes and errors; 'overlapping of design and construction' (Keys et al., 2000); and long project durations that allow the design to be modified to suit changes in the market, research or legislation (Poon et al., 2004; Ekanayake and Ofori, 2000) are significant DW causes.

Waste estimation tools provide the essential basis for understanding causes, types and quantities of construction waste arising from building designs (Wu et al., 2014). Prior knowledge of waste in a project will enable assessment of their management possibilities, including the waste prevention (Llatas, 2013). However, the complexity of the construction process and the involvement of a diverse number of stakeholders across different project stages make it difficult to realistically predict the types and quantities of onsite waste streams. This is further hindered by an imperceptible stakeholders' allocation of waste minimization responsibilities. As such, a recent study defined and related origins, causes and sources of waste across all project life stages and concluded that "waste generation is affected by a wide practice of not embedding 
LLatas, C and Osmani, M (2016) Development and validation of a building design waste reduction model, Waste Management (In Press)

DOI: 10.1016/j.wasman.2016.05.026.

waste reduction in briefing and contractual documents, no baseline setting, and lack of designers' understanding of design waste origins, causes and sources" (Osmani, 2013).

\subsection{Design waste reduction strategies}

A growing body of literature (Osmani et al., 2008; Baldwin et al., 2006; Poon et al. 2004; Greenwood, 2003) indicates that designers play a pivotal role in reducing onsite CW. Coventry and Guthrie (1998) assigned to architects a triple role in reducing waste: giving advice to customers, improving design practices and initiating waste reduction at project level. Over the past decade, several studies with different approaches identified strategies to reduce DW in the project that can be grouped into soft and hard strategies. Within the first group, modulation, standardization and optimization were identified as effective designing out waste strategies for several reasons. The modulation of the project and dimensional coherence of products improve coordination at project level as it prevents design modifications and abortive work during site operations (Coventry and Guthrie, 1998). The standardization of design applied to both the use of standard dimensions and units, such as the use of standard materials, reduces the off-cuts and improves buildability (Hylands, 2004). The optimization of buildability solutions was deemed as an appropriate waste minimization strategy to streamline designs that conventionally require more material than necessary as a result of over-specification resulting in unused materials that generally skipped and landfilled (Greenwood, 2003).

Other studies focused on hard strategies to recover waste through the development of cleaner technologies. Regarding the use of reclaimed CDW, designers can influence reusability and recyclability potential through the selection and specification of appropriate materials and structural systems, component types and their connections (Kartam et al., 2004; Gibb, 2001; Coventry and Guthrie, 1998). Cleaner technologies, pre-casting and prefabrication were identified as efficient design strategies because they offer significant opportunities to reduce waste (Baldwin et al., 2006) and better control of waste and damage avoidance (Dainty and Brooke, 2004). A limited number of research studies quantified the levels of waste reduction achieved with the use of prefabrication in buildings. These studies obtained overall wastage reduction levels up to 52\% (Jaillon et al., 2008); $84.7 \%$ (Tam et al., 2007a) and even 100\% 
LLatas, C and Osmani, M (2016) Development and validation of a building design waste reduction model, Waste Management (In Press)

DOI: 10.1016/j.wasman.2016.05.026.

(Tam et al., 2007b). In addition, these investigations identified building systems that were most

affected, estimating reduction of $74-87 \%$ in timber formwork and $51-60 \%$ in concrete works

(Tam et al., 2005) and 70\% in building finishing works on site concreting (Lawton et al., 2002).

Table 1 highlights the key literature causes that related waste streams to their respective sources and used prefabrication systems to quantify the levels of $\mathrm{CW}$ reduction.

Table 1 Design waste (DW) streams, causes, strategies and reduction (compiled from literature)

\begin{tabular}{|c|c|c|c|c|}
\hline Waste stream & Source/Cause & Design strategy & $\begin{array}{c}\% \\
\text { reduced }\end{array}$ & Study \\
\hline Construction waste & non-prefabrication & prefabrication & $\begin{array}{c}52 \%^{\mathrm{a}}-84.7 \%^{\mathrm{b}}-100 \%{ }^{\mathrm{c}} \\
\text { of } \\
\text { all construction waste }\end{array}$ & $\begin{array}{c}\text { Jaillon et al. } \\
(2008)^{\mathrm{a}} ; \text { Tam et al. } \\
(2007 \mathrm{a})^{\mathrm{b}} ; \text { Tam et al. } \\
(2007 \mathrm{~b})^{\mathrm{c}}\end{array}$ \\
\hline \multirow{2}{*}{ Concrete } & \multirow{2}{*}{ in-situ concreting } & $\begin{array}{l}\text { volumetric } \\
\text { prefabrication }\end{array}$ & $\begin{array}{c}70 \% \text { of } \\
\text { in-situ concreting }\end{array}$ & Lawton et al. (2002) \\
\hline & & prefabrication & $\begin{array}{c}51-60 \% \text { of } \\
\text { concrete works }\end{array}$ & Tam et al. (2005) \\
\hline $\begin{array}{l}\text { Mortar, plaster, } \\
\text { paints }\end{array}$ & $\begin{array}{l}\text { building finishing } \\
\text { works on-site }\end{array}$ & $\begin{array}{l}\text { volumetric } \\
\text { prefabrication }\end{array}$ & $\begin{array}{c}70 \% \text { of } \\
\text { building finishing } \\
\text { works on-site } \\
\end{array}$ & Lawton et al. (2002) \\
\hline Timber formwork & $\begin{array}{l}\text { in-situ concreting } \\
\text { the major contributor to } \\
\text { CW } 30 \% \text { of all waste } \\
\end{array}$ & prefabrication & $\begin{array}{c}74-87 \% \text { of } \\
\text { timber formwork }\end{array}$ & $\begin{array}{c}\text { Poon et al. } \\
(2004)^{\mathrm{a}} ; \text { Tam et al. } \\
(2005)^{\mathrm{b}}\end{array}$ \\
\hline $\begin{array}{l}\text { Wet trades, } \\
\text { concreting, } \\
\text { masonry, } \\
\text { plastering and } \\
\text { tiling } \\
\end{array}$ & $\begin{array}{l}\text { the second major } \\
\text { waste generator, } \\
20 \% \text { of all waste. }\end{array}$ & prefabrication & not noted & Poon et al. (2004) \\
\hline \multirow[t]{2}{*}{ Off-cuts } & \multirow[t]{2}{*}{$\begin{array}{l}\text { cutting materials, } \\
\text { inadequate dimensional } \\
\text { coordination, } \\
\text { design complexity }\end{array}$} & modulation & not noted & $\begin{array}{c}\text { Jaillon et al. } \\
\text { (2008); Coventry and } \\
\text { Guthrie } \\
\text { (1998); Bossink and } \\
\text { Brouwers (1996) }\end{array}$ \\
\hline & & $\begin{array}{l}\text { use of standard } \\
\text { materials }\end{array}$ & not noted & $\begin{array}{l}\text { Osmani (2013); } \\
\text { Hylands (2004) }\end{array}$ \\
\hline Unused materials & $\begin{array}{c}\text { over-specification, } \\
\text { lack of specifications }\end{array}$ & optimization & not noted & Greenwood (2003) \\
\hline Breakages & selection of low-quality materials & not noted & not noted & $\begin{array}{l}\text { Ekanayake and Ofori } \\
(2000)\end{array}$ \\
\hline Soil waste & unforeseen ground conditions & not noted & not noted & Poon et al. (2004) \\
\hline On-site activities & $\begin{array}{c}\text { architects' failure to implement } \\
\text { waste reduction measures during } \\
\text { design stages }\end{array}$ & not noted & $\begin{array}{c}33 \% \text { of } \\
\text { on-site waste }\end{array}$ & Innes (2004) \\
\hline $\begin{array}{l}\text { Rework and } \\
\text { partial demolitions }\end{array}$ & design changes (several causes) & not noted & not noted & $\begin{array}{c}\text { Won et al. } \\
\text { (2016); Cheng et al. } \\
\text { (2015); Poon et al. } \\
\text { (2004); Poon and } \\
\text { Jaillon } \\
\text { (2002); Chandrakanthi } \\
\text { et al. } \\
\text { (2002); Ekanayake } \\
\text { and Ofori } \\
\text { (2000); Keys et al. } \\
\text { (2000) }\end{array}$ \\
\hline
\end{tabular}


However, there is a lack of quantitative approaches to assess the effects of each prefabricated component on the overall waste reduction rate in buildings. Studies that adopted a qualitative approach evaluated alternative building elements and developed tools obtaining a benchmarking score in the projects according to their level of waste reduction (Ekanayake and Ofori, 2004). A growing number of tools, have been developed, such as SMARTWaste (BRE, 2007), as a means of recording and generating data on the quantities and types of onsite waste streams. However, these tools do not associate onsite waste to its source evaluation, particularly design waste. Moreover, despite the potential use of Building Information Modelling (BIM) techniques by architects as a platform for minimizing construction waste in their design projects, there are hardly any BIM applications in current practice that address design out waste in an integrated manner with the other design parameters (Liu, et.al., 2015), Therefore, there is a lack of methods and design tools, that identify waste streams in relation to their project stage incidence, as indicated by Osmani et al. (2008), and as such it is difficult to analyze the traceability of waste generated. Moreover, despite well-established recognition of the impact of design on the reduction of waste in literature, DW research efforts in the last decade are limited if compared with CDW recycling studies (Yuan and Shen, 2011).

Although existing literature emphasizes the correlation between design and $\mathrm{CW}$ reduction, there is a lack of methods and tools that address their relationships. Therefore, this research set out to develop and validate a model for DW reduction strategies using a quantitative, traceable and structured approach.

\section{Methodology}

As shown in Figure 1, the adopted method is twofold: (1) develop a model for Building Design Waste Reduction Strategies (Waste ReSt); and (2) carry out a real-world case study to validate the Waste ReSt model, which has been applied to 20 new residential buildings. The resulting design waste strategies of this research are based on a systematic correlation between onsite waste generation of building systems and their respective design sources. The adopted methodological process for the development and validation of the building design waste reduction model is described and discussed in the sections below. 


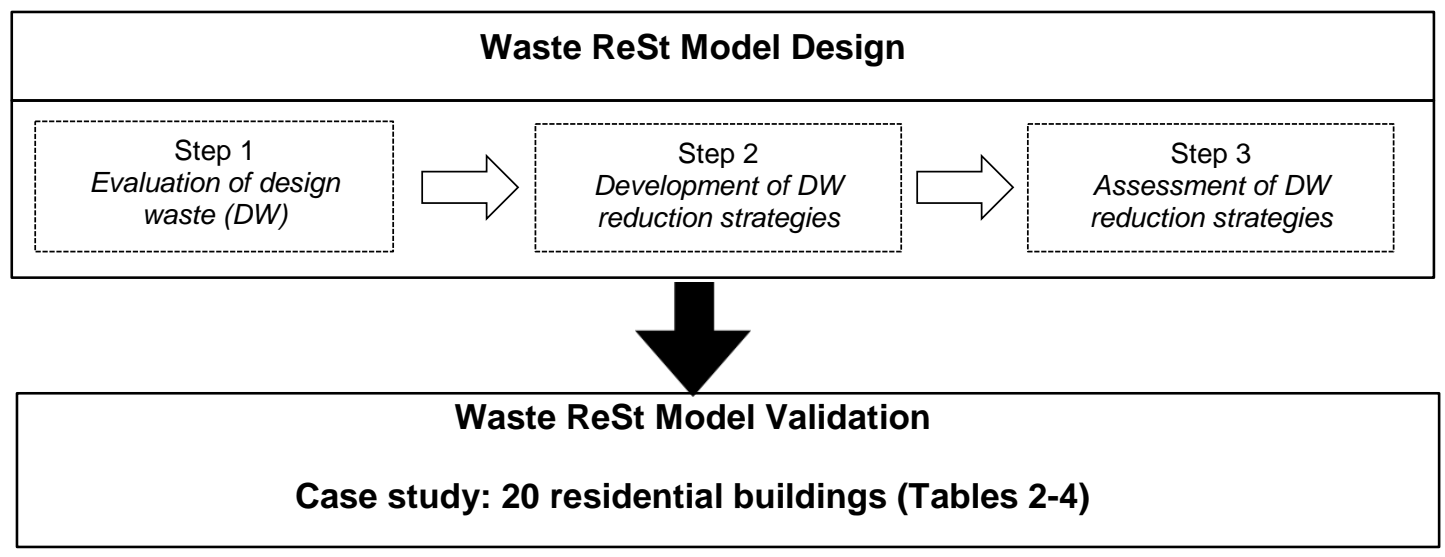

Figure 1 Waste reduction model methodological overview

\subsection{Model development methodological approach}

The approaches used in the literature to estimate the levels and classification of construction waste are mainly based on the experience of construction companies and developers through on-site measurements (Bossink and Brouwers, 1996; Pinto and Agopyan, 1994; Skoyles and Skoyles, 1987); surveys (Ekanayake and Ofori, 2004); documentary records (Forsythe and Marsden, 1999); and interviews (Serpell and Labra, 2003; Forsythe and Marsden, 1999). However a major barrier for CW prediction in projects is the absence of informed CW generation data that can be assessed during the pre-construction stages and extrapolated to the specificity of each project. To overcome this drawback, a CW quantification model is proposed in this paper. Unlike other approaches, the quantification model allows to estimate 'virtual' CW of each building element during the design process. The methodological development process of the Waste Rest model comprises three interdependent and consequential steps described below.

- Step 1: Evaluation of design waste (DW): Firstly, the types and amounts of DW can be estimated from seven DW factors (Table 5) by applying equations 1-5. DW is predicted by building element and classified according to the European Waste List (European Commission, 2014). Building elements and building systems can be identified within a systematic structure of the construction process (Andalusian Government, 2015). DW 
parameters that affect DW sources can be identified and assessed from their respective DW factor.

- Step 2: Development of DW reduction strategies: Secondly, DW reduction strategies (R 1.1. - R 8.2) that decrease DW can be developed (Table 6) by applying eight causal relationships (C1-C8) that relate DW factors, DW reduction strategies and reduced DW.

- Step 3: Assessment of DW reduction strategies: Thirdly, alternative building elements $\left(A_{i}^{j}\right)$ can be designed taking into account the latter DW reduction strategies. DW' factors can be allocated for these alternative building elements, and the types and amounts of reduced DW can be estimated by applying equations 6-9. Finally, the effectiveness of design waste reduction strategies in each building system can be achieved by applying equation 10 .

\subsection{Model validation case study}

A case study was carried out in Seville city in South of Spain to validate the Waste Rest model. The latter was applied to assess waste performance of building systems in 20 residential projects, which are listed in Table 2.

Table 2 Selected case study buildings

\begin{tabular}{cllcc}
\hline $\begin{array}{c}\text { Residential } \\
\text { Building }\end{array}$ & $\begin{array}{c}\text { Construction } \\
\text { Company }\end{array}$ & \multicolumn{1}{c}{ Description } & $\begin{array}{c}\text { Built area } \\
\mathbf{~ m}^{2}\end{array}$ & $\begin{array}{c}\text { Number of } \\
\text { stories }\end{array}$ \\
\hline B1 & VIAS & $\begin{array}{l}\text { 109 housing- } \\
\text { multi-family }\end{array}$ & 13910 & 8 \\
\hline B2 & VIAS & $\begin{array}{l}\text { 134 housing- } \\
\text { multi-family }\end{array}$ & 17981 & 9 \\
\hline B3 & Copcisa & $\begin{array}{l}\text { 204 housing- } \\
\text { multi-family }\end{array}$ & 23906 & 8 \\
\hline B4 & CYES & $\begin{array}{l}\text { 147 housing- } \\
\text { multi-family }\end{array}$ & 18592 & 9 \\
\hline B5 & San José & $\begin{array}{l}\text { 225 housing- } \\
\text { multi-family }\end{array}$ & 27375 & 8 \\
\hline B6 & Acciona & $\begin{array}{l}\text { 245 housing- } \\
\text { multi-family }\end{array}$ & 45705 & 9 \\
\hline B7 & Dragados & $\begin{array}{l}\text { 103 housing- } \\
\text { multi-family }\end{array}$ & 14112 & 6 \\
\hline B8 & Sanrocon & $\begin{array}{l}66 \text { housing- multi- } \\
\text { family }\end{array}$ & 7618 & 5 \\
\hline B9 & San José & $\begin{array}{l}27 \text { housing- multi- } \\
\text { family }\end{array}$ & 2882 & 4 \\
\hline B10-B20 & Several & 11 single-family & $120-250$ & $1-2$ \\
\hline
\end{tabular}


The validation case study sample was chosen as it is considered a representative situation of the current prevailing construction programmes in the Andalusian area, as shown in Tables 3 and 4. Therefore, the validation case study focussed on new residential buildings (Spanish Government, 2015).

Table 3 Types of buildings in Spain-Andalusia (Spanish Government, 2015)

\begin{tabular}{|c|c|c|}
\hline \multirow[b]{2}{*}{ Buildings by type of construction } & \multicolumn{2}{|c|}{$\begin{array}{l}\text { Statistics building } \\
\text { construction data } \\
\text { (Number of buildings/year) }\end{array}$} \\
\hline & Spain & Andalusia \\
\hline new residential buildings & 44,781 & 13,633 \\
\hline new non-residential buildings & 35,110 & 9,938 \\
\hline renovated buildings & 9,671 & 3,695 \\
\hline demolished buildings & 31,910 & 8,359 \\
\hline
\end{tabular}

There is also a higher incidence of multi-family buildings with a number of floors greater than four storey residential buildings (Spanish Government, 2015), aspect that was also taken into account in the sample selection. In terms of construction methods, the predominant techniques employed in the current Andalusian residential projects are conventional cast in situ structures, masonry external walls and partitions and mortar or plaster coatings (Spanish Government, 2015).

Table 4 Characteristics of residential buildings in Spain-Andalusia (Spanish Government, 2015)

\begin{tabular}{lcc}
\hline & Spain & $\begin{array}{c}\text { Statistics building } \\
\text { construction data } \\
\text { (Number of buildings, \%) }\end{array}$ \\
$\begin{array}{l}\text { Building by type of housing and } \\
\text { building system }\end{array}$ & Andalusia \\
\hline $\begin{array}{l}\text { Type of housing } \\
\text { single-family buildings }\end{array}$ & 32 & 36 \\
multi-family buildings & 68 & 64 \\
\hline Number of storeys & 8 & \\
0-1 floor & 26 & 8 \\
2 floors & 15 & 36 \\
3 floors & 51 & 18 \\
$>4$ floors & & 38 \\
\hline Structure & 72 & 91 \\
in-situ concreting & 6 & 2 \\
steel & 15 & 5 \\
brick walls & 7 & 2 \\
mixed and other & & \\
\hline Floors & 83 & 81 \\
in-situ concreting & 17 & 19 \\
\hline others & & \\
\hline
\end{tabular}




\begin{tabular}{lcc}
\hline \hline Roofing & 35 & \\
flat roof & 30 \\
pitched roof & 65 & 50 \\
\hline Exterior wall finishes & & \\
ceramic & 50 & 63 \\
stone & 13 & 3 \\
mortar & 32 & 31 \\
others & 5 & 3 \\
\hline
\end{tabular}

In-put data (DW factors of the reference building elements and their alternatives) was mainly collected through design documentation analysis and completed with onsite measurements and information gathering from suppliers and contractors. For example, the building materials, elements, systems and their design parameters were identified and quantified from projects' documentation of the case study buildings (B1-B20), mainly through the budget and design documentation (drawings, details, specifications of technical conditions). A subsequent analysis of the collected documentation provided information about the materials supplied their packaging and on-site logistical processes (collection, supply conditions, internal transport, execution, on-site manufacture of materials). All 20 buildings were under construction at the time of data collection although in different stages.

A major data collection barrier was the lack of output data, types and amounts of actual waste generated by building element. Waste data recorded by the construction companies were scarce and did not cover all waste streams neither all building systems. This situation was widespread in the construction sector in Spain during the period of the case study (2009-2012), which was reflected in the National Integrated Waste Plan 2007-2015 (Spanish Government Ministry of the Environment, 2009). The Plan noted that it was not possible to make estimates of C\&D waste given the lack of reliable statistics. The same challenge has already been highlighted in the validation of other models of waste minimization (e.g. Yuan et al., 2012) due to the unavailability of historical data that resulted in reverting to literature as the sole validation reference for the developed models. 
LLatas, C and Osmani, M (2016) Development and validation of a building design waste reduction model, Waste Management (In Press)

DOI: 10.1016/j.wasman.2016.05.026.

\section{Design waste reduction model development}

The Waste Rest Model design is illustrated in Figure 2 and described in the sections below.

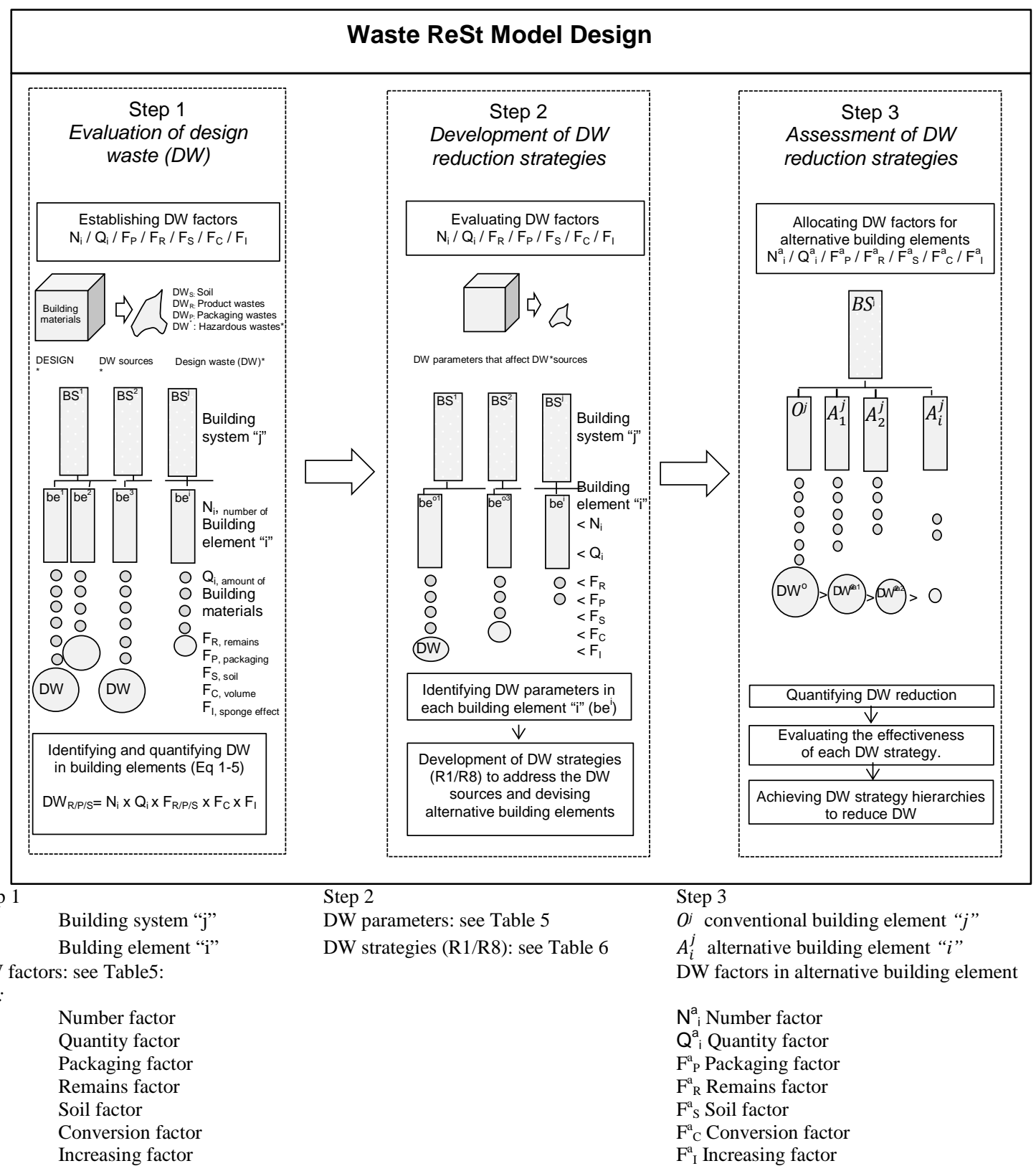

Figure 2 Waste ReSt model design 


\subsection{Step 1: Evaluation of design waste}

DW is analyzed in relation to seven DW factors that are defined in Table 5. The main sources of DW factors data are collected from project documents, statistical data from construction databases, material suppliers' information, execution process records provided by contractors, and onsite auditing and measurements.

Table 5 Design waste (DW) factors. Definitions and correlation with DW parameters

\begin{tabular}{|c|c|c|c|c|}
\hline & DW factor & Main source of data & Definition (a) & DW parameter \\
\hline $\mathrm{Ni}$ & Number factor & project document & $\begin{array}{l}\text { Number of building elements (be) ' } i \text { ' } \\
\text { necessary to execute the building system } \\
\text { (BS) ' } j \text { ' }\end{array}$ & Number of in situ processes. \\
\hline Qi & Quantity factor & $\begin{array}{l}\text { project document / } \\
\text { construction database }\end{array}$ & $\begin{array}{l}\text { Amount of building material necessary to } \\
\text { execute the building element number "i" in } \\
\text { the unit of measurement of the project (U) }\end{array}$ & $\begin{array}{l}\text { Amount of materials and } \\
\text { auxiliary resources }\end{array}$ \\
\hline$F_{P}$ & Packaging factor & material suppliers & $\begin{array}{l}\text { Ratio between the amount of packaging } \\
\text { waste in real volume }\left(\mathrm{m}^{3}\right) \text { and the amount } \\
\text { of building material in the unit of } \\
\text { measurement of the project }(U)\end{array}$ & $\begin{array}{l}\text { Packaging levels of the } \\
\text { products } \\
\text { Reused packagings }\end{array}$ \\
\hline$F_{R}$ & Remains factor & $\begin{array}{l}\text { construction database } \\
\text { / workers, builders, } \\
\text { contractors }\end{array}$ & $\begin{array}{l}\text { Ratio between the amount of remains to } \\
\text { be taken away from the site building in the } \\
\text { unit of measurement of the project }(U) \text { and } \\
\text { the amount of building material in the } \\
\text { project measuring unit }(U) \text {. }\end{array}$ & $\begin{array}{l}\text { Quality levels in the execution } \\
\text { Strength of materials } \\
\text { Quality levels in the details } \\
\text { Reused materials/products }\end{array}$ \\
\hline$F_{s}$ & Soil factor & project document & $\begin{array}{l}\text { Ratio between the amount of soil in real } \\
\text { volume }\left(\mathrm{m}^{3}\right) \text { and the amount of } \\
\text { building/site-work element in the project } \\
\text { unit }(U)\end{array}$ & $\begin{array}{l}\text { Amount of excavated soil } \\
\text { Reused soil }\end{array}$ \\
\hline$F_{c}$ & Conversion factor & project document & $\begin{array}{l}\text { Ratio between the amount of building } \\
\text { material expressed in real volume }\left(\mathrm{m}^{3}\right) \text { and } \\
\text { the amount of building material expressed } \\
\text { in the project measuring unit }(U) \text {. }\end{array}$ & Volume of the products \\
\hline$F_{I}$ & Increasing factor & in situ measurements & $\begin{array}{l}\text { Ratio between the amount of waste in } \\
\text { apparent volume }\left(\mathrm{m}^{3}\right) \text { and the amount of } \\
\text { waste in real volume }\left(\mathrm{m}^{3}\right)\end{array}$ & $\begin{array}{l}\text { Quality levels in the waste } \\
\text { collection }\end{array}$ \\
\hline
\end{tabular}

(a) Definitions made from Llatas (2011)

Once the DW factors are obtained, the types and amounts of DW are then estimated. Firstly, building elements, (e.g.: footings, catch-basins, beams, columns, collectors, etc.) are identified within the building systems, (e.g.: foundation, structure, masonry, roofing up to finish) according to the conventional sequence of construction processes. Secondly, the types of DW generated in each building system are identified and quantified by applying Eqs (1)-(5). The nomenclature and code of each type of waste follows the European Waste List (EWL) (European Commission, 2014). The EWL encoding allows distinguish four main groups of DW for each building element/system with different features: packaging waste $\left(\mathrm{DW}_{\mathrm{Pi}}\right)$, product waste 


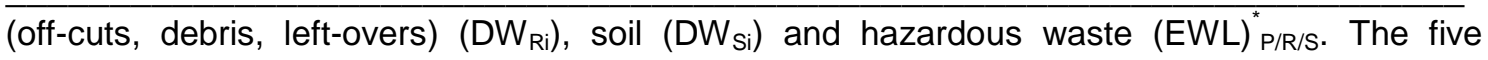
equations to identify and quantify DW in each building system are shown below.

1. $\mathrm{DW}_{\mathrm{BS}}=\sum_{j}^{i} N_{i} \cdot \mathrm{DW}_{\text {bei }}$

2. $\mathrm{DW}_{\mathrm{bei}}=\sum_{i} \mathrm{DW}_{\mathrm{Ri}}+\sum_{i} \mathrm{DW}_{\mathrm{Pi}}+\sum_{i} \mathrm{DW}_{\mathrm{Si}}$

3. $\mathrm{DW}_{\mathrm{Ri}}=\sum_{k}(\mathrm{EWL})_{\mathrm{Rk}} \cdot \mathrm{Q}_{\mathrm{i}} \cdot \mathrm{F}_{\mathrm{R}} \cdot \mathrm{F}_{\mathrm{C}} \cdot \mathrm{F}_{\mathrm{I}}$

4. $\mathrm{DW}_{\mathrm{Pi}}=\sum_{k}(\mathrm{EWL})_{\mathrm{Pk}} \cdot \mathrm{Q}_{\mathrm{i}} \cdot \mathrm{F}_{\mathrm{P}} \cdot \mathrm{F}_{\mathrm{C}} \cdot \mathrm{F}_{\mathrm{I}}$

5. $\mathrm{DW}_{\mathrm{Si}}=\sum_{k}(\mathrm{EWL})_{\mathrm{Sk}} \cdot \mathrm{Q}_{\mathrm{i}} \cdot \mathrm{F}_{\mathrm{S}} \cdot \mathrm{F}_{\mathrm{C}} \cdot \mathrm{F}_{\mathrm{I}}$

- $\mathrm{DW}_{\mathrm{BSj}}$ is the volume of the DW expected in the building system number " $\mathrm{j}$ ".

- DWbei is the volume of the DW expected in the building element number " $i$ ".

- $\mathrm{DW}_{\mathrm{Ri}}, \mathrm{DW}_{\mathrm{Pi}}, \mathrm{DW}_{\mathrm{Si}}$ are the volumes of the product waste, packaging waste and soil expected in the building element number "i".

- $(E W L)_{R k},(E W L)_{P k},(E W L)_{S k}(E W L)_{P / R / S}^{*}$ are the types of the product waste, packaging waste, soil and hazardous waste number "k" coded respectively according to the EWL.

- $N i, Q i, F_{P}, F_{R}, F_{S}, F_{C}, F_{l}$ are the DW factors of the building element "i".

Throughout this analysis DW parameters that affect DW sources can be identified and assessed from their respective DW factor. For example and as shown in Table 5, the design of building elements that requires more materials and auxiliary resources (DW parameter) increase Qi (DW factor) and therefore the appearance of damages of materials (DW sources) resulting in a greater amount of DW. This analysis can also be regressive, then starting with the detection of DW and ending with the assessment of its DW parameters. Therefore, the sequence of DW source-effect provided by the Waste ReSt model allows the traceability of wastes from their sources to their designing out waste parameters. This structured approach through the building process allow also the analysis of the waste origins as Osmani (2013) denoted, since the model can detect the project stages or processes during which wastes occurs. 


\section{4..2. Step 2: Development of design waste reduction strategies}

DW factors are related to the DW sources. Therefore, DW reduction strategies that address DW sources can decrease DW factors. Consequently, DW is reduced in accordance with Equations 1 to 5 . Table 6 shows the relationship between 34 DW reduction strategies classified into eight groups (R-1 to R-8), the DW factor affected and the type of reduced DW according to the following eight causal relationships (C1-C8):

(C1) If ' $N_{i}$ factor' decreases then $\mathrm{DW}_{\mathrm{Pi}}, \mathrm{DW}_{\mathrm{Ri}}$ and $\mathrm{DW}_{\mathrm{Si}}$ would be reduced. This will happen with seven strategies (R 1.1 to $R$ 1.7).

(C2) If ' $Q_{i}$ factor' decreases then $\mathrm{DW}_{\mathrm{P} \mathrm{i}}, \mathrm{DW}_{\mathrm{Ri}}$ and $\mathrm{DW}_{\mathrm{Si}}$ would be reduced. This will happen with six strategies (R 2.1 to $R 2.6$ ).

(C3) If ' $F_{P}$ factor' decreases then $\mathrm{DW}_{\mathrm{Pi}}$ would be reduced. This will happen with three strategies (R 3.1 to $R 3.3)$.

(C4) If ' $F_{R}$ factor' decreases then $\mathrm{DW}_{\mathrm{Ri}}$ would be reduced. This will happen with ten strategies (R 4.1 to $R 4.10)$.

(C5) If ' $F_{\mathrm{S}}$ factor' decreases then $\mathrm{DW} \mathrm{S}_{\mathrm{Si}}$ would be reduced. This will happen with two strategies (R 5.1 and R 5.2).

(C6) If ' $F_{C}$ factor' decreases then $\mathrm{DW}_{\mathrm{Pi}}, \mathrm{DW}_{\mathrm{Ri}}$ and $\mathrm{DW}_{\mathrm{Si}}$ would be reduced. This is linked with the strategy R 6.1.

(C7) If ' $F_{l}$ factor' decreases then $\mathrm{DW}_{\mathrm{Pi}}, \mathrm{DW}_{\mathrm{Ri}}$ and $\mathrm{DW}_{\mathrm{Si}}$ would be reduced. This will happen with three strategies depending on the waste source ( $R 7.1$ to $R$ 7.3).

(C8) Finally, the model also detects those building elements to which designers should pay more attention due to the possibility of generating hazardous waste. Therefore if $(E W L)^{*} P / R / S(E W L$ code hazardous waste) is removed, reduced, or replaced by a nonhazardous waste; hence potential to avoid cross waste contamination. This is particularly applicable to two strategies (R 8.1 and R 8.2). 
Table 6 Relationships between design waste reduction strategies, DW factors and types of reduced design wastes.

\begin{tabular}{|c|c|c|c|c|c|c|c|c|c|c|c|c|}
\hline \multicolumn{3}{|c|}{ Design waste reduction strategy } & \multicolumn{6}{|c|}{ Reduced DW factor } & \multicolumn{4}{|c|}{ Reduced design wastes } \\
\hline & & & \multirow{2}{*}{$\mathbf{N}_{\mathbf{i}}$} & \multirow[t]{2}{*}{$\mathbf{Q}_{\mathbf{i}}$} & \multirow[t]{2}{*}{$\mathbf{F}_{\mathrm{P}}$} & \multirow[t]{2}{*}{$F_{R}$} & \multirow[t]{2}{*}{$\mathbf{F}_{\mathrm{S}}$} & \multirow[t]{2}{*}{$F_{C} \quad F_{1}$} & \multirow[t]{2}{*}{$\mathrm{DW}_{\mathrm{Pi}}$} & \multirow[t]{2}{*}{$\mathrm{DW}_{\mathrm{Ri}}$} & \multirow{2}{*}{\multicolumn{2}{|c|}{$\mathrm{DW}_{\mathrm{Si}}(\mathrm{EWL}) * \mathrm{P} / \mathrm{R} / \mathrm{S}$}} \\
\hline R1 & Reduc & ing the number of building/site works elements & & & & & & & & & & \\
\hline & R1.1 & Need of the building element/material in the project & $\mathrm{X}$ & $\mathrm{X}$ & & & & & $x$ & $\mathrm{x}$ & $\mathrm{X}$ & \\
\hline & R1.2 & Equalization between excavated soil and backfill material & $\mathrm{X}$ & & & & $x$ & & & & $\mathrm{X}$ & \\
\hline & R1.3 & Avoidance of new building elements on site with respect to the project & $x$ & & & & & & $x$ & $x$ & & \\
\hline & R1.4 & Placement of prefabricated building elements & $\mathrm{x}$ & & $\mathrm{x}$ & $x$ & $\mathrm{x}$ & & $x$ & $x$ & & \\
\hline & R1.5 & Placement of building elements and components in dry & $x$ & & $x$ & $x$ & & & $x$ & $x$ & & \\
\hline & R1.6 & Planning and control of work at the time & $x$ & & $x$ & $x$ & $x$ & & $x$ & $x$ & $x$ & \\
\hline & R1.7 & Knowledge of recoverable waste from previous demolitions & $x$ & & $\mathrm{x}$ & $x$ & $x$ & & $x$ & $\mathrm{x}$ & $\mathrm{x}$ & \\
\hline \multirow[t]{7}{*}{$\mathbf{R 2}$} & Reduc & ing the amount of resources in building elements & & & & & & & & & & \\
\hline & R2.1 & Optimization of common elements by project area & & $x$ & & & & & $x$ & $x$ & & \\
\hline & R2.2 & Optimization of building elements & & $x$ & & & & & $x$ & $x$ & $\mathrm{x}$ & \\
\hline & R2.3 & Optimization of site-work excavation elements & & $x$ & & & $x$ & & & & $x$ & \\
\hline & R2.4 & Development of construction details that just do not generate waste & & $x$ & $x$ & $\mathrm{x}$ & & & $x$ & $\mathrm{x}$ & & \\
\hline & R2.5 & Use of pre-cast materials within building elements & & $x$ & & $x$ & & & $x$ & $x$ & & \\
\hline & R2.6 & Use of coated building materials & & $x$ & $x$ & $x$ & & & $x$ & $x$ & & \\
\hline \multirow[t]{4}{*}{ R3 } & Reduc & ing packaging waste & & & & & & & & & & \\
\hline & R3.1 & Use of building materials provided with optimized packaging & & & $x$ & & & & $x$ & & & \\
\hline & R3.2 & Use of materials provided without packaging & & & $x$ & & & & $x$ & & & \\
\hline & R3.3 & Recovery of packaging waste & & & $x$ & & & & $x$ & & & \\
\hline \multirow[t]{11}{*}{ R4 } & Reduc & ing losses & & & & & & & & & & \\
\hline & R4.1 & Proper collection and supply of materials & & & $x$ & $\mathrm{x}$ & & & $x$ & $x$ & & \\
\hline & R4.2 & Higher quality standards of the implementation process & & & & $x$ & & & & $x$ & & \\
\hline & R4.3 & Dimensional coordination & & & $x$ & $x$ & & & $x$ & $x$ & & \\
\hline & R4.4 & Use of resistant building materials & & & & $x$ & & & & $x$ & & \\
\hline & R4.5 & Use of special pieces & & & & $x$ & & & & $x$ & & \\
\hline & R4.6 & Removal of partial demolitions & $x$ & & & $x$ & & & & $x$ & & \\
\hline & R4.7 & Use of pre-elaborated building materials & $x$ & & & $x$ & & & & $x$ & & \\
\hline & R4.8 & Use of recoverable auxiliary materials & $x$ & & & $x$ & & & & $x$ & & \\
\hline & R4.9 & Use of recoverable and durable auxiliary materials & & $x$ & & $x$ & & & & $x$ & & \\
\hline & R4.10 & Use of building elements with less auxiliary materials & & $x$ & & $x$ & & & & & & \\
\hline \multirow[t]{3}{*}{ R5 } & Reduc & ing soil & & & & & & & & & & \\
\hline & R5.1 & Use of building elements that take up less volume in the ground & & & & & $x$ & & & & $x$ & \\
\hline & R5.2 & Reuse the excavated soil as fill material & $x$ & & & & $x$ & & & & $x$ & \\
\hline \multirow[t]{2}{*}{$\mathbf{R 6}$} & Reduc & ing the volume / weight of resources & & & & & & & & & & \\
\hline & R6.1 & Use of materials that meet the same function with less space/weight & & & & & & $x$ & & $x$ & & \\
\hline \multirow[t]{4}{*}{ R7 } & Reduc & ing the volume of waste in their collection & & & & & & & & & & \\
\hline & R7.1 & Compactness in the collection of packaging waste & & & & & & $x$ & $x$ & & & \\
\hline & R7.2 & Compactness in the collection of debris & & & & & & $x$ & & $x$ & & \\
\hline & R7.3 & Compactness in the collection of soil & & & & & & $x$ & & & $x$ & \\
\hline \multirow[t]{3}{*}{ R8 } & Reduc & ing hazardous waste & & & & & & & & & & \\
\hline & R8.1 & Elimination, reduction of materials with some characteristic of danger & & $X^{*}$ & $x$ & $x$ & $x$ & & & & & $x$ \\
\hline & R8.2 & Use of alternative materials to hazardous materials & & $x^{*}$ & & & & & & & & $x$ \\
\hline
\end{tabular}

R: Design waste reduction strategy; $\mathrm{N}_{\mathrm{i}}$ : Number factor; $\mathrm{Q}_{\mathrm{i}}$ : Quantity factor; $\mathrm{F}_{\mathrm{p}}$ : Packaging factor; $\mathrm{F}_{\mathrm{R}}$ : Remains factor; $\mathrm{F}_{\mathrm{s}}$ : Soil factor; $\mathrm{F}_{\mathrm{C}}$ : Conversion factor; $\mathrm{F}_{\mathrm{l}}$ : Increasing factor; $\mathrm{DW}_{\mathrm{Pi}}$ : packaging waste; $\mathrm{DW}_{\mathrm{Ri}}$ : product waste; $\mathrm{DW}_{\mathrm{Si}}$ : soil; $(\mathrm{EWL})^{\star}$ hazardous waste 


\section{3. Step 3: Assessment of design waste reduction strategies}

Within each building system " $j$ ", attributes that influence DW generation $\left(a^{1}, a^{2}, a^{3}, a^{n}\right)$ can be identified to design alternative building elements " $i$ " $\left(A_{i}^{j}\right)$ The conventional building element $\left(O^{j}\right)$ is defined as the building element which attributes $\left(0^{1}, 0^{2}, 0^{3}, 0^{n}\right)$ have a major impact on waste generation and hence are used as a reference for calculating DW reduction. DW reduction strategies are applied to associated DW sources in accordance with Table 6, resulting in alternative building elements " $i$ " $\left(A_{i}^{j}\right)$ as shown in Figure 2. Subsequently, DW factors are allocated for these alternative building elements. Thereby, the waste expected to be reduced in each conventional building element $\left(O^{\prime}\right)$ in the alternatives is calculated as the addition of the product waste, packaging waste and soil. The four equations to identify and quantify DW reduction in each building system are noted below.

6. $\mathrm{DW}_{\mathrm{Oi}}{ }^{R}=\sum_{i} \mathrm{DW}_{\mathrm{ORi}}{ }^{R}+\sum_{i} \mathrm{DW}_{\mathrm{OPi}^{R}}+\sum_{i} \mathrm{DW}_{\mathrm{OSi}}{ }^{R}$

7. $\mathrm{DW}_{\mathrm{ORi}}{ }^{R}=\sum_{k}(\mathrm{EWL})_{\mathrm{Rk}} \cdot\left(\mathrm{Q}_{\mathrm{i}}{ }^{O j}-\mathrm{Q}_{\mathrm{i}}{ }^{A j i}\right) \cdot\left(\mathrm{F}_{\mathrm{R}}{ }^{O j}-\mathrm{F}_{\mathrm{R}}{ }^{A j i}\right) \cdot\left(\mathrm{F}_{\mathrm{C}}{ }^{O j}-\mathrm{F}_{\mathrm{C}}{ }^{A j i}\right) \cdot\left(\mathrm{F}_{\mathrm{I}}^{O j}-\mathrm{F}_{\mathrm{I}}^{A j i}\right)$

8. $\mathrm{DW}_{\mathrm{OPi}}{ }^{R}=\sum_{k}(\mathrm{EWL})_{\mathrm{Pk}} \cdot\left(\mathrm{Q}_{\mathrm{i}}{ }^{O j}-\mathrm{Q}_{\mathrm{i}}^{A j i}\right) \cdot\left(\mathrm{F}_{\mathrm{P}}{ }^{O j}-\mathrm{F}_{\mathrm{P}}{ }^{A j i}\right) \cdot\left(\mathrm{F}_{C}{ }^{O j}-\mathrm{F}_{C}{ }^{A j i}\right) \cdot\left(\mathrm{F}_{\mathrm{I}}^{O j}-\mathrm{F}_{\mathrm{I}}^{A j i}\right)$

9. $\mathrm{DW}_{\mathrm{OSi}}{ }^{R}=\sum_{k}(\mathrm{EWL})_{\mathrm{Sk}} \cdot\left(\mathrm{Q}_{\mathrm{i}}{ }^{O j}-\mathrm{Q}_{\mathrm{i}}{ }^{A j i}\right) \cdot\left(\mathrm{F}_{\mathrm{S}}{ }^{O j}-\mathrm{F}_{\mathrm{S}}{ }^{A j i}\right) \cdot\left(\mathrm{F}_{\mathrm{C}}{ }^{j}-\mathrm{F}_{\mathrm{C}}{ }^{A j i}\right) \cdot\left(\mathrm{F}_{\mathrm{I}}^{O j}-\mathrm{F}_{\mathrm{I}}^{A j i}\right)$

- $\mathrm{DW}_{O i}{ }^{R}$ is the volume of the design waste expected to be reduced in the conventional building element number "j" $\left(O^{j}\right)$ with respect the alternative building element "i" $\left(A_{i}^{j}\right)$.

- $\quad \mathrm{DW}_{\mathrm{ORi}}{ }^{R}, \mathrm{DW}_{\mathrm{OPi}}{ }^{R}, \mathrm{DW}_{\mathrm{OSi}}{ }^{R}$ are the volumes of the product waste, packaging waste and soil expected to be reduced.

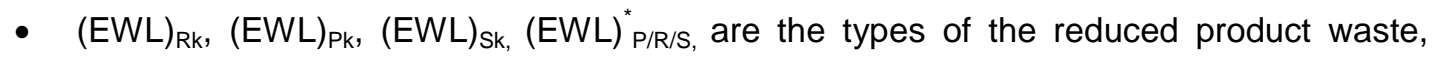
packaging waste, soil and hazardous number "k" coded respectively according to the EWL.

- $\quad \mathrm{Q}_{\mathrm{i}}^{{ }^{j}}, \mathrm{~F}_{\mathrm{R}}{ }^{o j}, \mathrm{~F}_{\mathrm{P}}{ }^{o j}, \mathrm{~F}_{\mathrm{S}}{ }^{o j}, \mathrm{~F}_{\mathrm{C}}{ }^{o j}, \mathrm{~F}_{\mathrm{I}}^{o j}$ are the $\mathrm{DW}$ factors of the conventional building element “j” $\left(O^{j}\right)$ and $\mathrm{Q}_{\mathrm{i}}^{A j i}, \mathrm{~F}_{\mathrm{R}}{ }^{A j i}, \mathrm{~F}_{\mathrm{P}}{ }^{A j i}, \mathrm{~F}_{\mathrm{S}}{ }^{A j i}, \mathrm{~F}_{\mathrm{C}}{ }^{A j i}, \mathrm{~F}_{\mathrm{I}}^{A j i}$ are the DW factors of the alternative building element "i" $\left(A_{i}^{j}\right)$. 
The model obtains the levels of DW reduction in volume instead of weight because it takes into account the compaction of waste collection in the work that will result in the optimization of the waste containers and in a greater efficiency in their transport. However, DW factors can be redefined to obtain the DW reductions in weight, in particular ' $F_{C}^{\prime}$ and ' $F_{I}^{\prime}$ factors. The unit of comparison is "volume of reduced waste/U", $U$ is the unit of measurement of the building element. From this data, other forms of comparison can be obtained, such as "volume of reduced waste $/ \mathrm{m}^{2}$ of construction floor area". Finally, the model allows the evaluation of the effectiveness of waste source reduction of each design strategy by applying the equation 10 and the attainment of a design waste reduction performance hierarchy.

10. $\mathrm{E}_{R i}^{j}=\frac{D W A_{j}^{a}-D W A_{j}^{b}}{D W A_{j}^{a}} \times 100$

- $\mathrm{E}_{R i}^{j}$ is the effectiveness of the design waste reduction strategy $\left(\mathrm{R}_{\mathrm{i}}\right)$ in each subsystem (j)

- $D W A_{a}^{j}$ is the volume of wastes generated by the building element $A_{a}^{j}$

- $D W A_{b}^{j}$ is the volume of wastes generated by the building element $A_{a}^{j}$ after applying the design waste reduction strategy $\left(R_{i}\right)$

\section{Model validation results}

The verification and validation of the Waste ReSt model was performed in a real-world case study involving 20 residential buildings in Spain (B1-B20), described in section '3.2. Model validation case study'. The validation case study enabled the evaluation of design waste sources and design reduction strategies related to thirteen building systems. The Waste ReSt model validation results are discussed below.

\subsection{Evaluation of design waste}

The systematic structure of the construction process was conducted according to the Banco de Costes de la Construccion en Andalucia (construction cost database of Andalusia) (Andalusian Government, 2015) because the projects were drafted in accordance with this structure. Thirteen building systems were identified from project documents. Within each building system, building elements with common functional features were identified. Table 7 
LLatas, C and Osmani, M (2016) Development and validation of a building design waste reduction model, Waste Management (In Press)

DOI: $10.1016 /$ j.wasman.2016.05.026.

shows the nine building sub-systems (01-09) most waste generators and representative building elements.

Table 7 Design wastes (DW) attributes, amounts, compositions and sources in building elements

\begin{tabular}{|c|c|c|c|c|c|c|c|}
\hline \multirow[b]{2}{*}{$\begin{array}{l}\text { Building } \\
\text { system (j) }\end{array}$} & \multirow[b]{2}{*}{$\mathbf{N}_{\mathbf{i}}$} & \multirow[b]{2}{*}{$\mathbf{U}$} & \multirow{2}{*}{$\begin{array}{l}\text { Building element (i) } \\
\text { /main conventional } \\
\text { attributes } I\left(0^{n}\right)\end{array}$} & \multirow{2}{*}{$\begin{array}{c}\begin{array}{c}\text { DW } \\
\text { amount }\end{array} \\
\frac{\mathrm{m}^{3}}{}\end{array}$} & \multicolumn{2}{|c|}{$\begin{array}{c}\text { DW } \\
\text { composition }\end{array}$} & \multirow[b]{2}{*}{$\begin{array}{l}\text { Resulting onsite } \\
\text { waste streams }\end{array}$} \\
\hline & & & & & $\begin{array}{c}\text { DW } \\
\text { stream }\end{array}$ & $\%$ & \\
\hline \multicolumn{8}{|c|}{ Foundation (01) } \\
\hline & 1.00 & $\mathrm{~m}^{3}$ & Cast in situ footings & 1.538 & soil & 96 & excavated soil \\
\hline & & & depth $=4.00 \mathrm{~m}$ & & concrete & 2 & cast in situ concrete losses \\
\hline & & & formwork type= brick wall & & bricks & 1 & broken bricks \\
\hline & & & packaging type $=$ sacks of cement & & wood & 1 & broken wooden pallets \\
\hline \multicolumn{8}{|c|}{ Structure, columns and beams (02); floors-(03) } \\
\hline & 1.00 & $\mathrm{~m}^{3}$ & Cast in situ columns & 0.027 & concrete & 83 & cast in situ concrete losses \\
\hline & & & formwork type=metallic & & metallic* & 15 & release agent cans \\
\hline & 1.00 & $\mathrm{~m}^{3}$ & Cast in situ beams & 0.110 & wood* & 77 & damaged timber formwork \\
\hline & & & formwork type= timber & & concrete & 20 & cast in situ concrete losses \\
\hline & & & & & metallic* & 3 & release agent cans \\
\hline & 1.00 & $m^{2}$ & Cast in situ floor & 0.015 & concrete & 40 & broken inter-joist blocks \\
\hline & & & type: one-way floor $25+5$ & & wood & 31 & broken wooden pallets \\
\hline & & & joist type $=$ pre-cast & & concrete & 13 & cast in situ concrete losses \\
\hline & & & inter-joist type $=$ concrete block & & wood & 11 & timber formwork losses \\
\hline \multicolumn{8}{|c|}{ Masonry, exterior walls (04); interior walls-(05) } \\
\hline & 1.00 & $\mathrm{~m}^{2}$ & Brick wall & 0.025 & wood & 47 & broken wooden pallets \\
\hline & & & thick $=11.5 \mathrm{~cm}$ & & bricks & 28 & broken hollow bricks \\
\hline & & & type $=$ hollow brick $9 \mathrm{~cm}$ & & cardboards & 9 & broken sacks \\
\hline & & & modulation $=$ uncoordinated & & concrete & 6 & mortar and cement losses \\
\hline & & & mortar type=in-situ & & plastic & 6 & brick plastic protection \\
\hline & & & packaging type=sacks & & soil & 2 & in-situ mortar sand losses \\
\hline \multicolumn{8}{|c|}{ Roofing (06) } \\
\hline & 1.00 & $\mathrm{~m}^{2}$ & Cast in situ flat roof & 0.028 & wood & 49 & broken wooden pallets \\
\hline & & & average thickness $=10 \mathrm{~cm}$ & & concrete & 16 & cast in situ concrete and mortar spills \\
\hline & & & slope type= in-situ mortar & & cardboards & 14 & broken sacks \\
\hline & & & flooring type= adhered & & soil & 7 & In-situ mortar aggregates losses \\
\hline \multicolumn{8}{|c|}{ Finishing, wall finishes (07); floor finishes (08); ceiling finishes (09) } \\
\hline & 1.00 & $m^{2}$ & Mortar plaster & 0.002 & concrete & 46 & in situ mortar losses \\
\hline & & & manufacturing type $=$ in-situ & & cardboards & 27 & broken cement sacks \\
\hline & 1.00 & $\mathrm{~m}^{2}$ & Gypsum plaster & 0.001 & wood & 37 & broken wooden pallets \\
\hline & & & manufacturing type $=$ in-situ & & gypsum & 33 & gypsum spills \\
\hline & & & packaging type=bags & & plastic & 29 & broken bags \\
\hline & 1.00 & $m^{2}$ & Ceramic tiles on walls & 0.005 & cardboards & 27 & broken boxes and sacks \\
\hline & & & grip type= in-situ mortar & & plastic & 23 & broken plastic protections \\
\hline & & & modulation $=$ uncoordinated & & ceramics & 16 & broken and cut tiles \\
\hline & 1.00 & $\mathrm{~m}^{2}$ & $\begin{array}{l}\text { Painting } \\
\text { packaging type=cans }\end{array}$ & 0.001 & $\begin{array}{l}\text { metallic* } \\
\text { paints* }\end{array}$ & $\begin{array}{c}98 \\
1\end{array}$ & $\begin{array}{l}\text { broken cans } \\
\text { paint spills }\end{array}$ \\
\hline
\end{tabular}

$\mathrm{N}_{\mathrm{i}}$ : Number factor; $\mathrm{U}$ : measurement unit; * potentially hazardous waste

Once DW factors were obtained, as indicated in Table 5, waste sources were then identified. Table 8 . shows the main sources of building material wastes used in the case study buildings. It highlights the inherent relationship between the type and amount of supplied 
LLatas, C and Osmani, M (2016) Development and validation of a building design waste reduction model, Waste Management (In Press)

DOI: 10.1016/j.wasman.2016.05.026.

building materials and the generated onsite waste types and amounts. The same approach was

adopted to assess streams and volumes of hazardous wastes.

Table 8 Sources of building material waste

\begin{tabular}{|c|c|c|c|c|c|c|c|}
\hline$Q_{i}$ & $\mathbf{U}$ & Building materials & $F_{R}$ & $F_{c}$ & $F_{1}$ & $\begin{array}{l}\text { Building material } \\
\text { waste stream }\end{array}$ & $\begin{array}{l}\text { DW Volume }\left(\mathrm{m}^{3}\right) \\
Q_{i} \times F_{R} \times F_{C} \times F_{1}\end{array}$ \\
\hline \multicolumn{8}{|c|}{ Concrete, mortar and gypsum } \\
\hline 1.00 & $\mathrm{~m}^{3}$ & mass concrete executed on site & 0.06 & 1.00 & 1.10 & concrete & 0.0660 \\
\hline 1.00 & $\mathrm{~m}^{3}$ & ready-mixed mass concrete & 0.04 & 1.00 & 1.10 & concrete & 0.0440 \\
\hline 1.00 & $\mathrm{~m}^{3}$ & reinforced concrete executed on site & 0.04 & 1.00 & 1.10 & concrete & 0.0440 \\
\hline 1.00 & $\mathrm{~m}^{3}$ & ready-mixed reinforced concrete & 0.02 & 1.00 & 1.10 & concrete & 0.0220 \\
\hline 1.00 & $\mathrm{~m}^{3}$ & mortar executed on site & 0.03 & 1.00 & 1.10 & concrete & 0.0330 \\
\hline 1.00 & $\mathrm{~m}^{3}$ & ready-mixed mortar & 0.01 & 1.00 & 1.10 & concrete & 0.0110 \\
\hline 1.00 & $\mathrm{u}$ & mortar block, $15 \times 20 \times 40 \mathrm{~cm}$ & 0.04 & 0.01 & 1.30 & concrete & 0.0006 \\
\hline 1.00 & $\mathrm{u}$ & concrete block inter-joist (floors) & 0.06 & 0.03 & 0.65 & concrete & 0.0012 \\
\hline 1.00 & u & terrazzo tile, $40 \times 40 \mathrm{~cm}$ & 0.04 & 0.03 & 1.20 & concrete & 0.0014 \\
\hline 1.00 & $\mathrm{t}$ & cement powder & 0.01 & 0.71 & 1.10 & concrete & 0.0079 \\
\hline 1.00 & $\mathrm{~m}^{3}$ & gypsum & 0.02 & 1.00 & 1.10 & gypsum & 0.0220 \\
\hline \multicolumn{8}{|l|}{ Bricks } \\
\hline 1.00 & $\mathrm{u}$ & hollow brick, thick: $9 \mathrm{~cm}$ & 0.06 & 0.00 & 1.30 & bricks & 0.0002 \\
\hline 1.00 & u & hollow brick, thick: $7 \mathrm{~cm}$ & 0.06 & 0.00 & 1.30 & bricks & 0.0001 \\
\hline 1.00 & u & hollow brick, thick: $4 \mathrm{~cm}$ & 0.06 & 0.00 & 1.30 & bricks & 0.0001 \\
\hline 1.00 & u & solid brick, thick: $4 \mathrm{~cm}$ & 0.05 & 0.00 & 1.25 & bricks & 0.0001 \\
\hline 1.00 & $\mathrm{u}$ & ceramic block, $15 \times 20 \times 40 \mathrm{~cm}$ & 0.02 & 0.01 & 1.30 & bricks & 0.0003 \\
\hline \multicolumn{8}{|c|}{ Tiles, ceramics } \\
\hline 1.00 & u & ceramic tile, $15 \times 15 \mathrm{~cm}$ & 0.06 & 0.00 & 1.30 & ceramics & 0.0000 \\
\hline 1.00 & $\mathrm{u}$ & ceramic tile, $14 \times 28 \mathrm{~cm}$ & 0.06 & 0.00 & 1.30 & ceramics & 0.0000 \\
\hline 1.00 & $\mathrm{u}$ & stoneware tile, $14 \times 28 \mathrm{~cm}$ & 0.03 & 0.00 & 1.30 & ceramics & 0.0000 \\
\hline 1.00 & u & ceramic block inter-joist (floors) & 0.02 & 0.03 & 0.65 & ceramics & 0.0004 \\
\hline 1.00 & $\mathrm{u}$ & sanitary facility (e.g. sink $50 \mathrm{~cm}$ ) & 0.02 & 0.02 & 1.30 & ceramics & 0.0004 \\
\hline \multicolumn{8}{|c|}{ Mixtures concrete and bricks } \\
\hline 1.00 & $\mathrm{~m}$ & circuits inside walls & 0.00 & 1.00 & 1.30 & mixtures & 0.0013 \\
\hline 1.00 & $\mathrm{~m}^{2}$ & demolished brick wall, thick: $4 \mathrm{~cm}$ & 1.00 & 0.04 & 1.30 & mixtures & 0.0520 \\
\hline \multicolumn{8}{|c|}{ Glass, plastic, wood and bituminous } \\
\hline 1.00 & $\mathrm{~m}^{2}$ & pane of glass $5 \mathrm{~mm}$ & 0.02 & 0.01 & 2.00 & glass & 0.0002 \\
\hline 1.00 & $\mathrm{~m}$ & PVC pipe, diam. $110 \mathrm{~mm}$ & 0.02 & 0.01 & 1.10 & plastic & 0.0002 \\
\hline 1.00 & $\mathrm{~m}^{2}$ & polyethylene sheet, thick: $0.20 \mathrm{~mm}$ & 0.05 & 0.00 & 2.00 & plastic & 0.0000 \\
\hline 1.00 & $\mathrm{~m}^{2}$ & wood stave flooring, $18 \mathrm{~mm}$ & 0.05 & 0.02 & 1.70 & wood & 0.0015 \\
\hline 1.00 & $\mathrm{~m}^{2}$ & asphalt membrane, thick: $4 \mathrm{~mm}$ & 0.02 & 0.00 & 1.10 & bituminous & 0.0001 \\
\hline \multicolumn{8}{|l|}{ Metals } \\
\hline 1.00 & $\mathrm{~m}$ & copper pipe, diam. 13/15 mm & 0.01 & 0.00 & 1.10 & copper & 0.0000 \\
\hline 1.00 & $\mathrm{~kg}$ & steel reinforcement & 0.01 & 0.00 & 1.10 & iron & 0.0000 \\
\hline \multicolumn{8}{|c|}{ Insulation } \\
\hline 1.00 & $m^{2}$ & polystyrene panel, thick: $4 \mathrm{~cm}$ & 0.01 & 0.04 & 1.10 & insulation & 0.0004 \\
\hline \multicolumn{8}{|c|}{ Others (due to testing, safety equipment, auxiliary materials, garbage, etc.) } \\
\hline 1.00 & $\mathrm{~m}^{3}$ & $\Sigma$ construction waste & 0.01 & 1.00 & 1.00 & mixed & 0.0100 \\
\hline \multicolumn{8}{|c|}{ Potentially hazardous } \\
\hline 1.00 & 1 & release agent (if organic solvents) & 0.02 & 0.00 & 1.00 & paints* & 0.0000 \\
\hline 1.00 & 1 & plasticizer (if organic solvents) & 0.02 & 0.00 & 1.00 & paints* & 0.0000 \\
\hline 1.00 & $\mathrm{~kg}$ & paint (if organic solvents) & 0.02 & 0.00 & 1.00 & paints* & 0.0000 \\
\hline 1.00 & $\mathrm{~kg}$ & adhesive (if organic solvents) & 0.02 & 0.00 & 1.00 & adhesives* & 0.0000 \\
\hline 1.00 & $\mathrm{~m}^{2}$ & timber formworks in beams & 0.01 & 1.00 & 1.70 & wood $^{*}$ & 0.0136 \\
\hline 1.00 & $\mathrm{~m}^{2}$ & timber formworks in floors & 0.02 & 1.00 & 1.70 & wood* $^{*}$ & 0.0340 \\
\hline 1.00 & $m^{2}$ & metallic formworks in columns & 0.00 & 1.00 & 1.10 & iron* $^{\star}$ & 0.0008 \\
\hline 1.00 & $\mathrm{~m}$ & cable $10 \mathrm{~mm}^{2}$ (if hydrocarbons) & 0.01 & 0.00 & 1.10 & cables* & 0.0000 \\
\hline 1.00 & $\mathrm{~m}^{2}$ & fiberglass panel, $4 \mathrm{~cm}$ (if asbestos) & 0.01 & 0.04 & 1.10 & insulation* & 0.0004 \\
\hline
\end{tabular}

$\mathrm{Q}_{\mathrm{i}}$ : Quantity factor; U: measurement unit; $\mathrm{F}_{\mathrm{R}}$ : Remains factor; $\mathrm{F}_{\mathrm{C}}$ : Conversion factor; $\mathrm{F}_{\mathrm{l}}$ : Increasing factor. * Potentially

hazardous waste. 
Table 9, which shows the main sources of packaging wastes, illustrates the relationship between the types and amounts of the supplied conventional as well as hazardous building materials and their associated packaging wastes.

Table 9 Sources of packaging waste

\begin{tabular}{|c|c|c|c|c|c|c|c|}
\hline $\mathbf{Q}_{\mathrm{i}}$ & $\mathbf{U}$ & Building materials & $F_{p}$ & $F_{c}$ & $F_{1}$ & $\begin{array}{c}\text { Packaging } \\
\text { waste stream }\end{array}$ & $\begin{array}{c}\text { Volume }\left(\mathrm{m}^{3}\right) \\
Q_{\mathrm{i}} \times \mathrm{F}_{\mathrm{E}} \times \mathrm{F}_{\mathrm{C}} \times \mathrm{F}_{\mathrm{I}}\end{array}$ \\
\hline \multicolumn{8}{|c|}{ Wooden pallets } \\
\hline 1.00 & $\mathrm{mu}$ & bricks & 0.25 & 1.00 & 1.10 & wood & 0.2750 \\
\hline 1.00 & $\mathrm{mu}$ & ceramic tiles, $14 \times 28 \mathrm{~cm}$ & 0.29 & 1.00 & 1.10 & wood & 0.3234 \\
\hline 1.00 & $\mathrm{u}$ & block inter-joist & 0.00 & 1.00 & 1.10 & wood & 0.0008 \\
\hline 1.00 & $\mathrm{u}$ & mortar block & 0.00 & 1.00 & 1.10 & wood & 0.0017 \\
\hline 1.00 & $\mathrm{t}$ & sacks/bags of cement, lime or gypsum & 0.02 & 1.00 & 1.10 & wood & 0.0275 \\
\hline 1.00 & $\mathrm{u}$ & terrazzo, concrete or stone tile & 0.00 & 1.00 & 1.10 & wood & 0.0003 \\
\hline 1.00 & $\mathrm{~m}$ & concrete joist & 0.00 & 1.00 & 1.10 & wood & 0.0003 \\
\hline 1.00 & $\mathrm{~m}^{2}$ & scagliola plate & 0.00 & 1.00 & 1.10 & wood & 0.0041 \\
\hline \multicolumn{8}{|c|}{ Cardboard boxes } \\
\hline 1.00 & u & small electrical equipment & 0.00 & 1.00 & 0.25 & cardboard & 0.0001 \\
\hline 1.00 & $\mathrm{~m}$ & cable & 0.00 & 1.00 & 0.25 & cardboard & 0.0001 \\
\hline 1.00 & $\mathrm{u}$ & luminaire, lamp & 0.01 & 1.00 & 0.25 & cardboard & 0.0014 \\
\hline 1.00 & $\mathrm{u}$ & plumbing material (stopcocks) & 0.01 & 1.00 & 0.25 & cardboard & 0.0014 \\
\hline 1.00 & $\mathrm{u}$ & sanitary facility, (e.g. sink) & 0.05 & 1.00 & 0.25 & cardboard & 0.0125 \\
\hline 1.00 & $\mathrm{u}$ & glazed tile & 0.00 & 1.00 & 0.25 & cardboard & 0.0000 \\
\hline 1.00 & $m^{2}$ & carpentry (auxiliary hardware) & 0.00 & 1.00 & 0.25 & cardboard & 0.0001 \\
\hline 1.00 & $\mathrm{~m}^{2}$ & glass (protection of panels) & 0.01 & 1.00 & 0.25 & cardboard & 0.0020 \\
\hline \multicolumn{8}{|c|}{ Cardboard sacks } \\
\hline 1.00 & $\mathrm{t}$ & cement , lime & 0.75 & 1.00 & 0.10 & cardboard & 0.0750 \\
\hline \multicolumn{8}{|c|}{ Plastic bags } \\
\hline 1.00 & $\mathrm{t}$ & gypsum, scagliola & 0.75 & 1.00 & 0.10 & plastic & 0.0750 \\
\hline 1.00 & $m^{3}$ & cardboard boxes & 0.40 & 1.00 & 2.00 & plastic & 0.8000 \\
\hline 1.00 & $\mathrm{~m}^{3}$ & wooden pallets (ceramic, sacks) & 0.06 & 1.00 & 2.00 & plastic & 0.1200 \\
\hline \multicolumn{8}{|c|}{ Metallic/plastic cans } \\
\hline 1.00 & 1 & non-hazardous liquid & 0.00 & 1.00 & 1.30 & metallic & 0.0012 \\
\hline 1.00 & $\mathrm{~kg}$ & non-hazardous liquid & 0.00 & 1.00 & 1.30 & metallic & 0.0008 \\
\hline \multicolumn{8}{|c|}{ Others (textiles, wire, polystyrenes, etc.) } \\
\hline 1.00 & $\mathrm{~m}^{3}$ & $\Sigma$ packaging waste & 0.01 & 1.00 & 1.00 & mixed & 0.0100 \\
\hline \multicolumn{8}{|c|}{ Potentially hazardous } \\
\hline 1.00 & 1 & hazardous liquid, pasty or solid matrix & 0.00 & 1.00 & 1.30 & liquid, solid matrix* & 0.0012 \\
\hline 1.00 & $\mathrm{~kg}$ & hazardous liquid, pasty or solid matrix & 0.00 & 1.00 & 1.30 & liquid, solid matrix* & 0.0008 \\
\hline
\end{tabular}

$\mathrm{Q}_{\mathrm{i}}$ : Quantity factor; U: measurement unit; $\mathrm{F}_{\mathrm{p}}$ : Packaging factor; $\mathrm{F}_{\mathrm{C}}$ : Conversion factor; $\mathrm{F}_{\mathrm{l}}$ : Increasing factor; DW: Design waste. Potentially hazardous waste.

Table 10 shows the main sources of soil waste provenance, types and volumes. This was mainly generated during the excavation of various site-works.

DW parameters, which were identified and analyzed in relation to their associated DW factors as indicated in Table 5, are described below.

- Remains Factor $\left(F_{R}\right)$ assessed the effects of quality levels in the execution of materials on waste generation. For example, in-situ mass concrete would generate $50 \%$ concrete waste more than ready-mixed mass concrete (Table 8).

- Conversion Factor $\left(F_{C}\right)$ assessed the effects of the volume of the products on waste generation. For example, $9 \mathrm{~cm}$ thick hollow bricks would generate $28 \%$ brick waste more than $7 \mathrm{~cm}$ thick hollow bricks (Table 8). 
- Remains Factor $\left(F_{R}\right)$ assessed the effects of the strength of materials on waste generation. For example, $4 \mathrm{~cm}$ thick hollow bricks would generate $24 \%$ brick waste more than $4 \mathrm{~cm}$ thick solid brick (Table 8).

- Packaging Factor $\left(F_{P}\right)$ assessed the effects of the packaging levels of the products on waste generation. For example, 1 ton of cement supplied in the form of sacks on pallets and covered with plastic would generate $0.1058 \mathrm{~m}^{3}$ packaging waste more than 1 ton cement silos (Table 9).

Table 10 Sources of excavation waste

\begin{tabular}{|c|c|c|c|c|c|c|c|}
\hline$Q_{i}$ & $\mathbf{U}$ & Excavation materials & $F_{s}$ & $F_{c}$ & $F_{1}$ & $\begin{array}{l}\text { Excavation } \\
\text { stream }\end{array}$ & $\begin{array}{c}\text { Volume }\left(m^{3}\right) \\
Q_{i} \times F_{s} \times F_{c} \times F_{1}\end{array}$ \\
\hline \multicolumn{8}{|c|}{ Organic soil } \\
\hline 1.00 & $\mathrm{~m}^{2}$ & site clearing (thick $=20 \mathrm{~cm}$ ) & 1.00 & 0.20 & 1.10 & organic soil & 0.2200 \\
\hline \multicolumn{8}{|c|}{ Soil and stones from ground } \\
\hline 1.00 & $\mathrm{~m}^{3}$ & excavation of basements & 1.00 & 1.00 & 1.25 & soil & 1.2500 \\
\hline 1.00 & $\mathrm{~m}^{3}$ & excavation of foundations & 1.00 & 1.00 & 1.25 & soil & 1.2500 \\
\hline 1.00 & $\mathrm{~m}^{2}$ & excavation of slabs (thick $=15 \mathrm{~cm}$ ) & 1.00 & 0.15 & 1.10 & soil & 0.1650 \\
\hline 1.00 & $\mathrm{u}$ & excavation of catch-basins $(51 \times 51 \times 100 \mathrm{~cm})$ & 1.00 & 0.77 & 1.20 & soil & 0.9216 \\
\hline \multicolumn{8}{|c|}{ Sand and stones from building materials } \\
\hline 1.00 & $\mathrm{~m}^{3}$ & sand (mortars and pavements) & 0.01 & 1.00 & 1.00 & soil & 0.0100 \\
\hline 1.00 & $\mathrm{~m}^{3}$ & gravel, albero fill & 0.01 & 1.00 & 1.00 & stones & 0.0100 \\
\hline 1.00 & u & granite tile in claddings, $40 \times 40 \mathrm{~cm}$ & 0.02 & 0.03 & 1.20 & stones & 0.0007 \\
\hline 1.00 & $\mathrm{u}$ & limestone tile in claddings, $40 \times 40 \mathrm{~cm}$ & 0.03 & 0.03 & 1.20 & stones & 0.0011 \\
\hline 1.00 & $\mathrm{u}$ & granite tile floorings, $40 \times 40 \mathrm{~cm}$ & 0.05 & 0.03 & 1.20 & stones & 0.0018 \\
\hline 1.00 & $\mathrm{u}$ & limestone tile floorings, $40 \times 40 \mathrm{~cm}$ & 0.06 & 0.03 & 1.20 & stones & 0.0022 \\
\hline 1.00 & $\mathrm{t}$ & lime powder & 0.01 & 1.00 & 1.10 & stones & 0.0110 \\
\hline \multicolumn{8}{|c|}{ Potentially hazardous } \\
\hline 1.00 & $\mathrm{~m}^{3}$ & soil (if hazardous substance) & 1.00 & 1.00 & 1.00 & contaminated soil ${ }^{*}$ & 1.0000 \\
\hline
\end{tabular}

Additionally, the identification of the hazardous materials allowed the analysis of the generation of hazardous waste. For example, $1 \mathrm{~kg}$ of paint with organic solvent would generate $0.0010 \mathrm{~m}^{3}$ of hazardous waste which could become non-hazardous waste in case of its substitution by paint without organic solvent (Tables 8 and 9).

Subsequently, expected wastes to be generated during the execution of building elements were estimated from knowledge of the materials used in their execution and their amounts $\left(\mathrm{Q}_{\mathrm{i}}\right)$. The identification and analysis of DW sources was accomplished according to the standard sequence of the execution of a construction program. Table 7 shows the major design waste sources that were identified. The main issues in the analysis of DW sources were:

- $\quad$ the identification of the major building elements' DW generators in each building system.

As shown in Table 7, ten types of building elements were identified across nine building 
sub-systems. Other building elements were found to be low waste generators; such as downspouts, buried piping and structural joints.

- the incidence of the types of generated DW in each building system. Table 7 shows the main DW sources of each building element and associated waste volume generation.

- $\quad$ the identification of the building elements most likely to generate hazardous waste. Table 7 shows the detected hazardous waste; and

- the analysis of the key attributes that affect DW source reduction, of which some of them have been included in Table 7.

\section{2. Development of design waste reduction strategies}

Within each building system " $j$ ", attributes that influenced DW generation $\left(a^{1}, a^{2}, a^{3}, a^{n}\right)$ were identified and conventional building elements $\left(\mathrm{O}^{j}\right)$ were developed. For example, in the foundation building system ("j:1"), major attributes were ' $\mathrm{a}^{1}$ (type of foundation)', ' $\mathrm{a}^{2}$ (the depth)' , ' $a^{3}$ (type of formworks) ';'a (type of packaging of the formwork-materials)' as shown in Table 7; and the conventional building element $\left(\mathrm{O}^{1}\right)$ with the highest waste generation attributes was 'cast in situ footings $\left(\mathrm{o}^{1}\right), 4 \mathrm{~m}$ average depth $\left(\mathrm{o}^{2}\right)$, permanent brick formwork $\left(\mathrm{o}^{3}\right)$, cement supplied in sack $\left(0^{4}\right)^{\prime}$ : as shown in Table 11. Therefore, the proposed DW reduction strategies were developed by replacing the conventional attributes $\left(0^{n}\right)$ by alternates $\left(a^{n}\right)$ that reduce or do not generate wastes. For example, foundation related waste could be reduced if the conventional attribute ' $\mathrm{o}^{3}$ (permanent brick formwork)' is replaced by a recoverable formwork such as 'timber formwork' or by a recoverable and durable formwork such as 'metal formwork'.

Tables 11 to 15 show examples of alternatives to conventional building elements $\left(\mathrm{O}^{j}\right)$ and the respective design waste reduction strategies that were applied. For each alternative, DW factors were obtained and DW was estimated according to the European Waste List (EWL). In the foundation building system (Table 11) for example, the building element $A_{1}^{1}$ was designed from $O^{1}$ by varying attribute 'a4'. The 'use of bulk mortar' (alternative attribute) instead of 'cement sacks' (conventional attribute) in the brick walls is comprised within two design strategies: 'R.3.2. use of materials provided without packaging' and 'R 4.7. use of pre-elaborated building materials`. These two strategies will lead to fewer material losses and 
LLatas, C and Osmani, M (2016) Development and validation of a building design waste reduction model, Waste Management (In Press)

DOI: 10.1016/j.wasman.2016.05.026.

less packaging waste. Other strategies were applied, such as: 'R5.2 reuse the excavated soil as fill material', 'R1.4 placement of prefabricated building elements' (e.g. pre-cast concrete piles), and 'R2.3 optimization of site-work excavation elements' (e.g. reduction of the depth of excavation). From the variation of the attributes may arise multiple alternative building elements $A_{i}^{j}$

Table 11 Alternative low waste foundation building systems and associated design waste reduction strategies

\begin{tabular}{|c|c|c|c|}
\hline Foundation building system (01) & $\begin{array}{c}\text { DW } \\
\text { Reduction } \\
\text { Strategy } \\
\end{array}$ & $\begin{array}{c}\text { DW } \\
\text { Total } \\
\left(\mathrm{m}^{3} / \mathrm{m}^{2}\right)\end{array}$ & $\begin{array}{c}\text { DW } \\
\text { Reduction } \\
\%\end{array}$ \\
\hline \multicolumn{4}{|l|}{ Foundation } \\
\hline$O^{1}$ Cast in situ footings, depth $4,00 \mathrm{~m}$, permanent brick formwork, cement sacks & & 0.26 & 0 \\
\hline$A_{1}^{1}$ Cast in situ footings, depth $4,00 \mathrm{~m}$, permanent brick formwork, bulk mortar & R3.2/R4.7 & 0.26 & 0 \\
\hline Cast in situ footings, depth $4,00 \mathrm{~m}$, recoverable timber formwork & R4.8 & 0.25 & 7 \\
\hline$A_{3}^{1}$ Cast in situ footings, depth $4,00 \mathrm{~m}$, recoverable metal formwork & $\mathrm{R} 4.9$ & 0.24 & 8 \\
\hline$A_{4}^{1}$ Cast in situ slab ${ }^{3}, 60 \mathrm{~cm}$ thic:, permanent brick formwork, cement sacks & R2.2 & 0.21 & 23 \\
\hline$A_{5}^{1}$ Cast in situ slab, thick: $60 \mathrm{~cm}$, permanent brick formwork, bulk mortar & R2.2/R3.2 & 0.21 & 23 \\
\hline$A_{6}^{1}$ Cast in situ slab, thick: $60 \mathrm{~cm}$, recoverable timber formwork & R2.2/R4.8 & 0.20 & 24 \\
\hline Cast in situ slab, thick: $60 \mathrm{~cm}$, recoverable metal formwork & R2.2/R4.9 & 0.20 & 24 \\
\hline Cast in situ footings, depth $2,00 \mathrm{~m}$, permanent brick formwork, cement sacks & $\mathrm{R} 2.3$ & 0.15 & 42 \\
\hline Pre-cast concrete piles, diam. $35 \mathrm{~cm}$, permanent brick formwork, cement sacks & $\mathrm{R} 1.4$ & 0.07 & 75 \\
\hline Pre-cast concrete piles, diam. $35 \mathrm{~cm}$, permanent brick formwork, bulk mortar & R1.4/R3.2 & 0.07 & 75 \\
\hline$A_{11}^{1} \quad$ Pre-cast concrete piles, diam. $35 \mathrm{~cm}$, recoverable timber formwork & R1.4/R4.8 & 0.06 & 78 \\
\hline$A_{12}^{1} \quad$ Pre-cast concrete piles, diam. $35 \mathrm{~cm}$, recoverable metal formwork & R1.4/R4.9 & 0.06 & 78 \\
\hline$A_{13}^{1}$ Cast in situ footings, soil reuse, depth $4,00 \mathrm{~m}$, brick formwork, cement sacks & R5.2 & 0.01 & 96 \\
\hline
\end{tabular}

DW Reduction Strategy coded according to Table.6; Oj: reference building element "j"; $A_{\mathrm{i}}^{\mathrm{j}}$ : alternative building element "i"

$\mathrm{m}^{2}$ refers to square meter of building floor area

In the structural building system (Table 12), the major attributes that affected the amount of wastes in columns and beams were: building materials (cast in situ, steel, pre-cast); the form of cast in situ delivery (executed on-site, ready-mixed); the design of beams (embedded, not embedded); the type of formworks (timber, metal); and the type of joint (dry, wet). The major attributes in the floor sub-system were: materials (cast in situ, pre-cast, steel); flooring type (beam and pot, waffle); type of joists (semi-resistant joists, self-resistant); and inter-joists type (concrete, ceramic, recoverable PVC). 
Table 12 Alternative low waste structural building systems and associated design waste reduction strategies

\begin{tabular}{|c|c|c|c|c|c|c|}
\hline \multicolumn{2}{|c|}{ Structural building system $(02,03)$} & $\begin{array}{c}\text { DW } \\
\text { Reduction } \\
\text { Strategy }\end{array}$ & $\begin{array}{c}\text { DW } \\
\text { packaging } \\
\left(\mathrm{m}^{3} / \mathrm{m}^{2}\right)\end{array}$ & $\begin{array}{c}\text { DW } \\
\text { product } \\
\left(\mathrm{m}^{3} / \mathrm{m}^{2}\right)\end{array}$ & $\begin{array}{c}\text { DW } \\
\text { Total } \\
\left(\mathrm{m}^{3} / \mathrm{m}^{2}\right)\end{array}$ & $\begin{array}{c}\text { DW } \\
\text { Reduction } \\
\% \\
\end{array}$ \\
\hline \multicolumn{7}{|c|}{ Columns and beams $(\mathrm{O} 2)$} \\
\hline$A_{1}^{2}$ & Brick wall, thick: $24 \mathrm{~cm}$, mortar on-site, not embedded beams, timber formwork & & 0.03 & 0.02 & 0.05 & -58 \\
\hline$O^{2}$ & Cast executed on site columns, not embedded beams, timber formwork release agent & & 0.01 & 0.03 & 0.03 & 0 \\
\hline$A_{1}^{2}$ & Cast executed on site columns, not embedded beams, timber formwork, release agent without OS & R8.2 & 0.01 & 0.03 & 0.03 & $0 / 100^{*}$ \\
\hline$A_{2}^{2}$ & Ready-mixed cast in situ columns, not embedded beams, timber formwork & R3.2/R4.7 & 0.00 & 0.03 & 0.03 & 21 \\
\hline$A_{3}^{2}$ & Ready-mixed cast in situ columns, metal formwork, not embedded beams, timber formwork & R3.2/R4.9 & 0.00 & 0.02 & 0.02 & 48 \\
\hline$A_{4}^{2}$ & Ready-mixed cast in situ columns, metal formwork, embedded beams, timber formwork & R3.2/R2.2 & 0.00 & 0.02 & 0.02 & 48 \\
\hline$A_{5}^{2}$ & Steel columns and beams encased in concrete on site, thick: $5 \mathrm{~cm}$ & R1.4 & 0.00 & 0.01 & 0.01 & 76 \\
\hline$A_{6}^{2}$ & Steel columns and beams encased in gypsum, thick: $2 \mathrm{~cm}$ & R1.4 & 0.00 & 0.00 & 0.01 & 85 \\
\hline$A_{7}^{2}$ & Pre-cast concrete columns and beams (wet-joint) & R1.4 & 0.00 & 0.00 & 0.00 & 95 \\
\hline$A_{8}^{2}$ & Steel columns and beams-sprayed fire proof & R1.4 & 0.00 & 0.00 & 0.00 & 96 \\
\hline$A_{9}^{2}$ & Pre-cast concrete columns and beams (dry-joint) & $\mathrm{R} 1.4 / \mathrm{R} 1.5$ & 0.00 & 0.00 & 0.00 & 100 \\
\hline \multicolumn{7}{|c|}{ Floors (03) } \\
\hline$O^{3}$ & Cast in situ waffle slab floor $25+5$, inter-joist concrete block & & 0.00 & 0.01 & 0.02 & 0 \\
\hline$A_{1}^{3}$ & Cast in situ beam and pot floor $25+5$, semi-resistant joists, concrete block & R2.5 & 0.00 & 0.01 & 0.01 & 18 \\
\hline$A_{2}^{3}$ & Cast in situ waffle slab floor $25+5$, recoverable inter-joist PVC block & R4.9 & 0.00 & 0.01 & 0.01 & 22 \\
\hline$A_{3}^{3}$ & Cast in situ beam and pot floor $25+5$, self-resistant -joists, concrete block & R2.5/R4.10 & 0.00 & 0.01 & 0.01 & 29 \\
\hline$A_{4}^{3}$ & Cast in situ beam and pot floor $25+5$, semi-resistant joists, ceramic block & R2.5/R4.4 & 0.01 & 0.01 & 0.01 & 39 \\
\hline$A_{5}^{3}$ & Cast in situ beam and pot floor $25+5$, self-resistant-joists, ceramic block & R2.5/R4.4/10 & 0.01 & 0.00 & 0.01 & 49 \\
\hline$A_{6}^{3}$ & Cast in situ waffle slab floor 25+5, recoverable self-resistant block & R4.9/ R4.10 & 0.00 & 0.01 & 0.01 & 56 \\
\hline$A_{7}^{3}$ & Pre-cast concrete hollow core slabs $16 \mathrm{~cm}$, concrete layer $4 \mathrm{~cm}$ & R1.4 & 0.00 & 0.00 & 0.00 & 85 \\
\hline$A_{8}^{3}$ & Pre-cast concrete hollow core slabs $16 \mathrm{~cm}$, without concrete layer & R1.4/R1.5 & 0.00 & 0.00 & 0.00 & 90 \\
\hline
\end{tabular}

DW Reduction Strategy is coded according to Table 5; Oj : conventional building element " $\mathrm{j}$ "; $\mathrm{A}_{\mathrm{i}}^{\mathrm{j}}$ : alternative building element " $\mathrm{i}$ "

$\mathrm{m}^{2}$ refers to square meter of building floor area. ${ }^{*}$ Remove $100 \%$ hazardous waste

In the masonry building system (Table 13), the key attributes were: materials (brick, precast concrete); material thickness (24-4 cm); type of brick (solid, hollow); material modulation (coordinated, uncoordinated); type of mortar delivery (bulk, cements sacks); and type pre-cast concrete joints (wet, dry). Other building elements that were also assessed included brick walls built and demolished as a result of design changes.

Table 13 Alternative low waste masonry building systems and associated design waste reduction strategies

\begin{tabular}{|c|c|c|c|c|c|}
\hline Masonry building system $(04,05)$ & $\begin{array}{c}\text { DW } \\
\text { Reduction } \\
\text { Strategy }\end{array}$ & $\begin{array}{c}\text { DW } \\
\text { packaging } \\
\left(\mathrm{m}^{3} / \mathrm{m}^{2}\right)\end{array}$ & $\begin{array}{c}\text { DW } \\
\text { product } \\
\left(\mathrm{m}^{3} / \mathrm{m}^{2}\right)\end{array}$ & $\begin{array}{c}\text { DW } \\
\text { Total } \\
\left(\mathrm{m}^{3} / \mathrm{m}^{2}\right)\end{array}$ & $\begin{array}{c}\text { DW } \\
\text { Reduction } \\
\%\end{array}$ \\
\hline \multicolumn{6}{|l|}{ Exterior Walls (04) } \\
\hline$O^{4}$ Brick wall, thick: $24,0 \mathrm{~cm}$, solid brick $4 \mathrm{~cm}$, cement sacks, uncoordinated & & 0.05 & 0.01 & 0.06 & 0 \\
\hline$A_{1}^{4} \quad$ Brick wall, thick: $24,0 \mathrm{~cm}$, solid brick $4 \mathrm{~cm}$, cement sacks, coordinated & R4.3 & 0.05 & 0.01 & 0.05 & 11 \\
\hline$A_{2}^{4}$ Brick wall, thick $24,0 \mathrm{~cm}$, innertube $10,0 \mathrm{~cm}$, hollow brick $7 \mathrm{~cm}$, cement sacks & R2.2/R6.1 & 0.03 & 0.01 & 0.04 & 30 \\
\hline$A_{3}^{4} \quad$ Brick wall, thick: $11,5 \mathrm{~cm}$, solid brick $4 \mathrm{~cm}$, cement sacks & R6.1 & 0.02 & 0.01 & 0.03 & 51 \\
\hline$A_{4}^{4}$ Brick wall, thick: $11,5 \mathrm{~cm}$, hollow brick $9 \mathrm{~cm}$, cement sacks & R6.1/R3.1 & 0.02 & 0.01 & 0.03 & 59 \\
\hline$A_{5}^{4} \quad$ Brick wall, thick: $11,5 \mathrm{~cm}$, hollow brick $9 \mathrm{~cm}$, mortar bulk & R6.1/R4.7 & 0.01 & 0.01 & 0.02 & 65 \\
\hline$A_{6}^{4} \quad$ Block wall, thick: $14,0 \mathrm{~cm}$, cement sacks & $\mathrm{R} 2.5$ & 0.02 & 0.01 & 0.02 & 68 \\
\hline$A_{7}^{4} \quad$ Pre-cast concrete panel, thick: $16 \mathrm{~cm}$ (wet-joint) & R1.4 & 0.00 & 0.00 & 0.00 & 95 \\
\hline$A_{8}^{4} \quad$ Pre-cast concrete panel, thick: $16 \mathrm{~cm}$ (dry-joint) & $\mathrm{R} 1.4 / \mathrm{R} 1.5$ & 0.00 & 0.00 & 0.00 & 98 \\
\hline \multicolumn{6}{|l|}{ Interior walls (05) } \\
\hline$A_{1}^{5}$ Brick wall built and demolished, thick: $4,0 \mathrm{~cm}$, hollow brick $4 \mathrm{~cm}$, cement sacks & R4.6 & 0.01 & 0.06 & 0.07 & -351 \\
\hline$O^{5}$ Brick wall, thick: $4,0 \mathrm{~cm}$, hollow brick $4 \mathrm{~cm}$, cement sacks & & 0.01 & 0.00 & 0.01 & 0 \\
\hline$A_{1}^{5} \quad$ Plasterboard panel, thick $5,0 \mathrm{~cm}$ & R1.4 & 0.00 & 0.00 & 0.00 & 72 \\
\hline
\end{tabular}

DW Reduction Strategy is coded according to Table 5; $O^{j}$ : conventional building element “" $\mathrm{j}^{\text {"; }} \mathrm{A}_{\mathrm{i}}^{\mathrm{j}}$ : alternative building element “i”"

$\mathrm{m}^{2}$ refers to square meter of wall 
As shown in Table 14, the main roofing building system attributes were: roof type (tiled, flat, steel beam); materials (ceramic, mortar); roof slope type (brick, mortar, steel beam); the slope and thickness $(150-10 \mathrm{~cm})$; tiling (mortar-adhered, adhesive-adhered, non-adhered, without tiling); and the mortar delivery (sacks, bulk).

Table 14 Alternative low waste roofing building systems and associated design waste reduction strategies

\begin{tabular}{|c|c|c|c|c|c|}
\hline $0^{6}$ Ceramic tiled roof on brick wall slopes, medium height $1.50 \mathrm{~m}$, cement sacks & & 0.04 & 0.02 & 0.05 & 0 \\
\hline$A_{1}^{6} \quad$ Mortar tiled roof on brick wall slopes, medium height $1.50 \mathrm{~m}$, cement sacks & R4.4 & 0.04 & 0.02 & 0.05 & 2 \\
\hline$A_{2}^{6} \quad$ Mortar tiled roof on brick wall slopes, medium height $1.50 \mathrm{~m}$, mortar bulk & R3.2/R4.4/7 & 0.03 & 0.01 & 0.05 & 11 \\
\hline$A_{3}^{6}$ Cast in situ flat roof, slope average thickness $10 \mathrm{~cm}$, mortar on-site, adhered paving & R2.2 & 0.02 & 0.01 & 0.03 & 47 \\
\hline$A_{6}^{6}$ Cast in situ inverted flat roof, slope average thickness $5 \mathrm{~cm}$, non-adhered tiling & R2.2/R6.1/R15 & 0.01 & 0.00 & 0.01 & 79 \\
\hline$A_{7}^{6} \quad$ Mortar tiled roof on steel beam, medium height $1.50 \mathrm{~m}$ & R1.4/R1.5 & 0.00 & 0.00 & 0.00 & 93 \\
\hline$A_{8}^{6}$ Cast in situ inverted flat roof, slope average thickness $5 \mathrm{~cm}$, non-tiling & R2.2/R6.1/R11 & 0.00 & 0.00 & 0.00 & 99 \\
\hline
\end{tabular}

DW Reduction Strategy is coded according to Table 5; $O^{j}$ : conventional building element " $\mathrm{j}^{\mathrm{j} \text {; }} \mathrm{A}_{\mathrm{i}}^{\mathrm{j}}$ : alternative building element "i" $\mathrm{m}^{2}$ refers to square meter of roof

In the finishing building system (Table 15), the major attributes were: materials (ceramic, stone, gypsum, mortar); material modulation (uncoordinated, coordinated); anchoring system (mortar grip, adhesive, mechanical); material delivery (bulk, sacks); and finishes (painting, without painting, only painting).

The alternatives $\left(A_{j}^{i}\right)$ for all building systems were ranked based on the achieved waste reduction levels with respect to the identified conventional building element $\left(O^{i}\right)$. This process led to the following key findings:

- The application of design waste reduction strategies led to a decrease of DW factors and associated waste types in accordance with Table 6.

- The Waste ReSt model allowed the assessment of waste reduction estimation of alternative building elements, which is absent from literature in terms of DW project decision-making.

- The obtained DW reduction levels with alternative building elements were variable, reaching in several cases almost $100 \%$. A subsequent analysis identified the most effective strategies in each building system, which is discussed in the section below. 
Table 15 Alternative low waste finishing building systems and associated design waste reduction strategies

\begin{tabular}{|c|c|c|c|c|c|}
\hline Finishing building systems (07-09) & $\begin{array}{c}\text { DW } \\
\text { Reduction } \\
\text { Strategy }\end{array}$ & $\begin{array}{c}\text { DW } \\
\text { packaging } \\
\left(\mathrm{m}^{3} / \mathrm{m}^{2}\right) \\
\end{array}$ & $\begin{array}{c}\text { DW } \\
\text { product } \\
\left(\mathrm{m}^{3} / \mathrm{m}^{2}\right)\end{array}$ & $\begin{array}{c}\text { DW } \\
\text { Total } \\
\left(\mathrm{m}^{3} / \mathrm{m}^{2}\right)\end{array}$ & $\begin{array}{c}\text { DW } \\
\text { Reduction } \\
\% \\
\end{array}$ \\
\hline \multicolumn{6}{|l|}{ Wall finishes (07) } \\
\hline$O^{7}$ Ceramic tiles, mortar grip, uncoordinated & & 0.003 & 0.002 & 0.005 & 0 \\
\hline$A_{1}^{7}$ Ceramic tiles, adhesive grip, uncoordinated & R2.2/R6.1 & 0.004 & 0.001 & 0.004 & 10 \\
\hline$A_{2}^{7} \quad$ Ceramic tiles, mortar grip, coordinated & R4.3 & 0.003 & 0.001 & 0.004 & 15 \\
\hline$A_{3}^{7}$ Ceramic tiles, adhesive grip, coordinated & R2.2/R6.1/ R4.3 & 0.004 & 0.000 & 0.004 & 25 \\
\hline$A_{4}^{7}$ Stone tiles, mortar grip, uncoordinated & $\mathrm{R} 4.4$ & 0.002 & 0.002 & 0.003 & 39 \\
\hline$A_{5}^{7} \quad$ Mortar on-site, cement sacks and painting & R6.1 & 0.001 & 0.001 & 0.002 & 55 \\
\hline$A_{6}^{7} \quad$ Gypsum plaster and painting & R6.1 & 0.002 & 0.000 & 0.002 & 59 \\
\hline$A_{7}^{7} \quad$ Coat mortar on-site, without painting & R2.6 & 0.001 & 0.001 & 0.002 & 70 \\
\hline$A_{8}^{7} \quad$ Cladding stone, mechanical anchorage & R1.5 & 0.001 & 0.000 & 0.001 & 75 \\
\hline$A_{9}^{7} \quad$ Gypsum plaster, bulk and painting & R3.2/R4.7 & 0.001 & 0.000 & 0.001 & 77 \\
\hline$A_{10}^{7}$ Mortar, ready-mixed, and painting & R3.2/R4.7 & 0.001 & 0.000 & 0.001 & 81 \\
\hline$A_{11}^{7}$ Painting finish only & R1.1 & 0.001 & 0.000 & 0.001 & 85 \\
\hline$A_{12}^{7}$ Coat mortar, ready-mixed, without painting & R2.6/R3.2/R4.7 & 0.000 & 0.000 & 0.000 & 95 \\
\hline \multicolumn{6}{|l|}{ Floor finishes (08) } \\
\hline$O^{8}$ Ceramic tiled finish, interrupted-partitions, uncoordinated, cement sacks & & 0.003 & 0.003 & 0.006 & 0 \\
\hline$A_{1}^{8}$ Limestone tiled finish, interrupted-partitions, uncoordinated, cement sacks & R4.4 & 0.003 & 0.003 & 0.006 & 2 \\
\hline$A_{2}^{8} \quad$ Terrazzo tiled finish, interrupted-partitions, uncoordinated, cement sacks & R4.4 & 0.003 & 0.002 & 0.005 & 9 \\
\hline$A_{3}^{8}$ Stoneware tiled finish, interrupted-partitions, uncoordinated, cement sacks & R4.4/ R6.1 & 0.003 & 0.002 & 0.005 & 11 \\
\hline$A_{4}^{8} \quad$ Terrazzo tiled finish, uninterrupted-partitions, uncoordinated, cement sacks & $\mathrm{R} 4.4 / \mathrm{R} 2.4$ & 0.003 & 0.002 & 0.005 & 19 \\
\hline$A_{5}^{8} \quad$ Terrazzo tiled finish, interrupted-partitions, coordinated, cement sacks & R4.4/ R4.3 & 0.002 & 0.002 & 0.004 & 22 \\
\hline$A_{6}^{8} \quad$ Terrazzo tiled finish, interrupted-partitions, uncoordinated, mortar bulk & R4.4/R3.2/R4.7 & 0.002 & 0.002 & 0.004 & 37 \\
\hline$A_{7}^{8} \quad$ Terrazzo tiled finish, uninterrupted-partitions, coordinated, mortar bulk & R4.4/3/R2.4/R47 & 0.002 & 0.001 & 0.002 & 58 \\
\hline$A_{8}^{8} \quad$ Carpet finish, adhesive & R2.2/ R6.1 & 0.001 & 0.000 & 0.001 & 86 \\
\hline$A_{9}^{8} \quad$ Epoxy coating finish & $\mathrm{R} 2.2 / \mathrm{R} 6.1$ & 0.000 & 0.000 & 0.000 & 99 \\
\hline \multicolumn{6}{|l|}{ Ceiling finishes (09) } \\
\hline $0^{9}$ Plaster false ceiling, bamboo branches and painting & & $0.006^{*}$ & $0.001^{*}$ & 0.006 & 0 \\
\hline$A_{1}^{9} \quad$ Timber planks and timber frame & R1.4/R1.5 & 0.005 & 0.001 & 0.006 & 1 \\
\hline$A_{2}^{9} \quad$ Plasterboard and painting & R1.4 & 0.005 & 0.000 & 0.006 & 7 \\
\hline$A_{3}^{9} \quad$ Aluminum strips and metal frame & R1.4/R1.5 & 0.004 & 0.000 & 0.004 & 32 \\
\hline$A_{4}^{9} \quad$ Mortar on-site, cement sacks and painting & R2.2/ R6.1 & 0.001 & 0.001 & 0.002 & 64 \\
\hline$A_{5}^{9} \quad$ Gypsum plaster and painting & $\mathrm{R} 2.2 / \mathrm{R} 6.1$ & 0.002 & 0.000 & 0.002 & 66 \\
\hline$A_{6}^{9} \quad$ Gypsum plaster, bulk and painting & R2.2/R6.1/R3.2/R4.7 & 0.001 & 0.000 & 0.001 & 84 \\
\hline$A_{7}^{9} \quad$ Mortar, ready-mixed, and painting & R2.2/R6.1/R3.2/R4.7 & 0.001 & 0.000 & 0.001 & 84 \\
\hline$A_{8}^{9} \quad$ Painting finish only & R1.1 & 0.001 & 0.000 & 0.001 & 89 \\
\hline
\end{tabular}

DW Reduction Strategy is coded according to Table 2; $O^{j}$ : conventional building element “j”; $A_{i}^{j}$ : alternative building element "i" ${ }^{2}$ refers to square meter of wall, of floor, of ceiling, in each case. ${ }^{*}$ Potentially hazardous waste.

\section{3. Assessment of design waste reduction strategies}

The next stage in the validation of the Waste ReSt model comprised the evaluation of the effectiveness of design waste reduction strategies in each building system obtained by applying equation 10. Figures 3 to 10 show the proposed DW strategies in nine building sub-systems (O1-09) that were used to replace conventional attributes by alternatives and the potential waste reduction levels. The eight Figures represent the impact of each design strategy on DW reduction. As shown in Figure 3, the strategy 'R 4.9 use of recoverable and durable auxiliary metal framework materials' would entail a 9\% reduction of total foundation waste generation, if compared to brick wall formworks that were used in the case study buildings. The most effective 
DW strategies were the reuse of soil; the use of pre-cast piles; and the optimization of the foundation design.

\section{Design Waste Reduction Strategy
Alternative attribute $\left(a^{n}\right)$ versus conventional attribute $\left(o^{n}\right)$}

\section{R5.2. Reuse soil}

$100 \%$ soil reused versus $100 \%$ soil landfilled

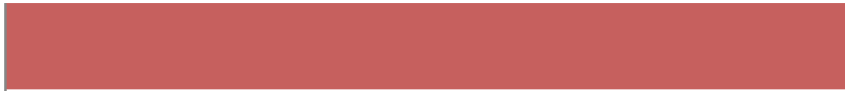

R1.4 Placement of prefabricated elements pre-cast concrete piles versus cast in situ footings

R2.3 Optimization of site-work excavation $2 \mathrm{~m}$ depth versus $4 \mathrm{~m}$ depth

R2.2 Optimization of the foundation cast in situ slab versus cast in situ footings

R4.9 Use of recoverable and durable auxiliary materials metal formworks versus brick wall formworks

R4.8 Use of recoverable auxiliary materials timber formworks versus brick wall formworks

R3.2 Use of materials provided without packaging bulk mortar versus mortar executed on-site
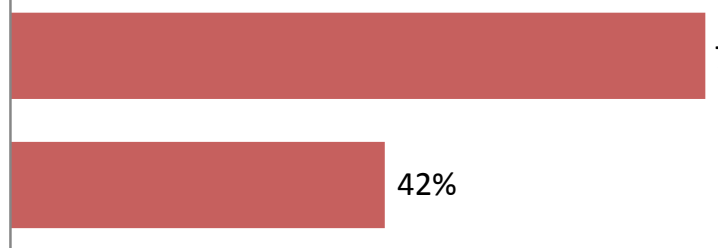

$42 \%$
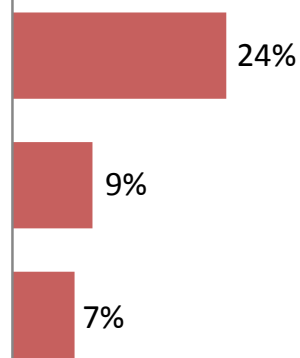

Figure 3 Achieved waste reduction levels in Foundation Building System (O1)

With regard the Structural Building System (Figures 4 and 5), the use of pre-cast concrete with dry joints was deemed the most effective strategy. Other DW strategies, such as the use of metal instead of timber formworks in cast in situ columns would entail a $27 \%$ reduction; the use of recoverable blocks in floors would reduce wastes by $21 \%$ and the use of release agent without OS in cast in situ would potentially achieve 100\% hazardous waste reduction (mainly timber formworks and contaminated packaging). 
LLatas, C and Osmani, M (2016) Development and validation of a building design waste reduction model, Waste Management (In Press)

DOI: 10.1016/j.wasman.2016.05.026.

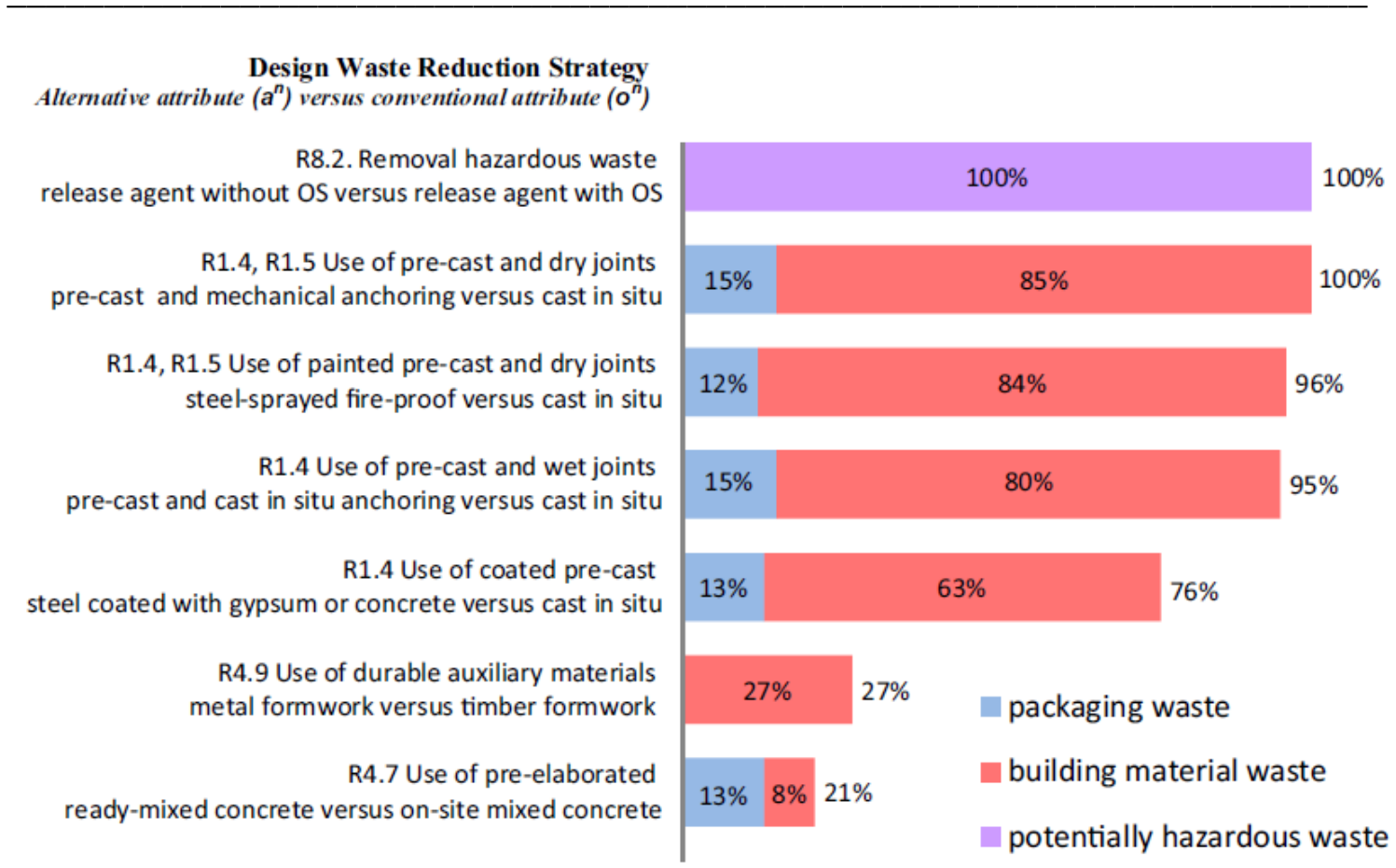

Figure 4 Achieved waste reduction levels in Structural Building System, columns and beams (O2)

Design Waste Reduction Strategy

R1.4, R1.5 Use of pre-cast and dry joints pre-cast concrete slab versus cast in situ slab

R1.4 Use of pre-cast and wet joints pre-cast concrete slab and cast in situ layer versus cast in situ slab

R4.10 Use of cast in situ with less formworks self-resistant inter-joist block versus non-resistant block

R4.9 Use of recoverable materials recoverable inter-joist block versus unrecoverable block

R4.4 Use of materials with less breakages ceramic inter-joist block versus concrete block

R4.7 Use of cast in situ with pre-cast pre-cast concrete joist versus cast in situ joist

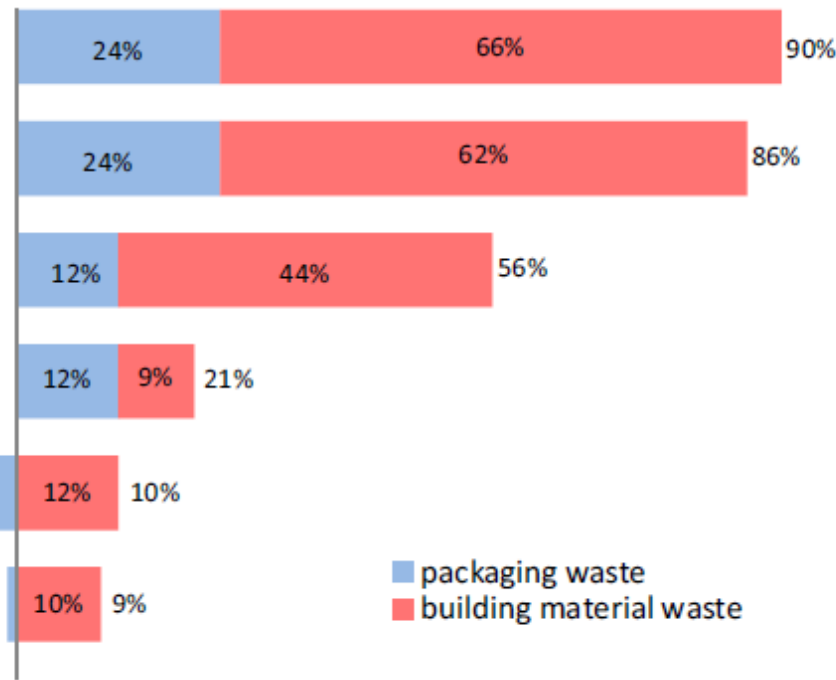

Figure 5 Achieved waste reduction levels in Structural Building System, floors (O3) 
In the Masonry Building System (Figure 6), the main DW strategies were the use of precast materials with mechanical anchoring, the use of blocks instead bricks, the modulation of brick walls and the use of preprocessed materials, such as ready-mixed mortar. For example, the recovery of wooden pallets would also entail a $68 \%$ of DW reduction.

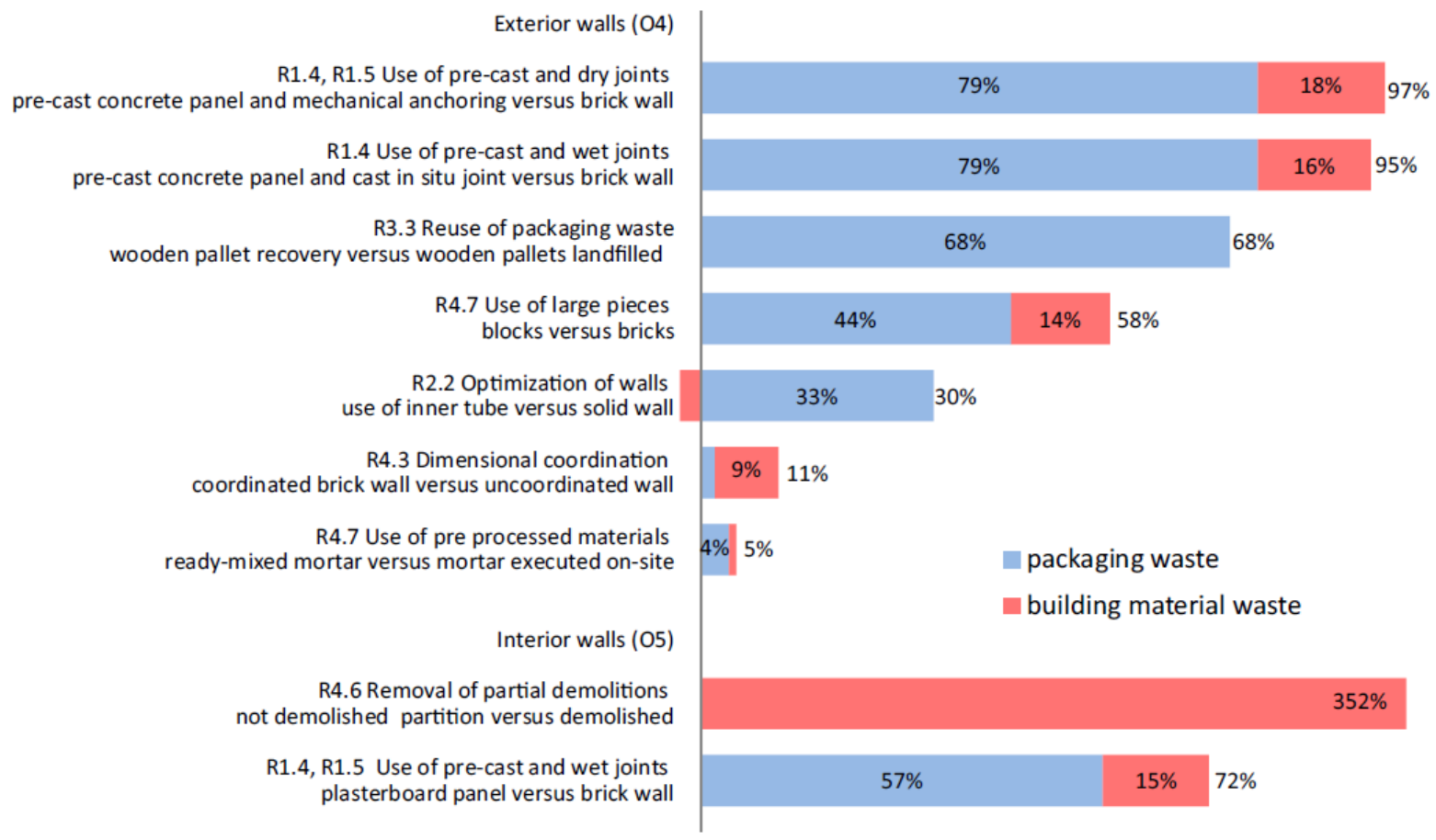

Figure 6 Achieved waste reduction levels in Masonry Building System $(04,05)$

In the Roofing Building System (Figure 7), the optimization of the slopes and the use of mechanical anchorage and materials with a dual function would entail a $7 \%$ and $20 \%$ reduction. The use of non-adhered tiles for example, would imply not only less building material wastes (1\% of total wastes) but also less packaging wastes (6\% of total wastes). 


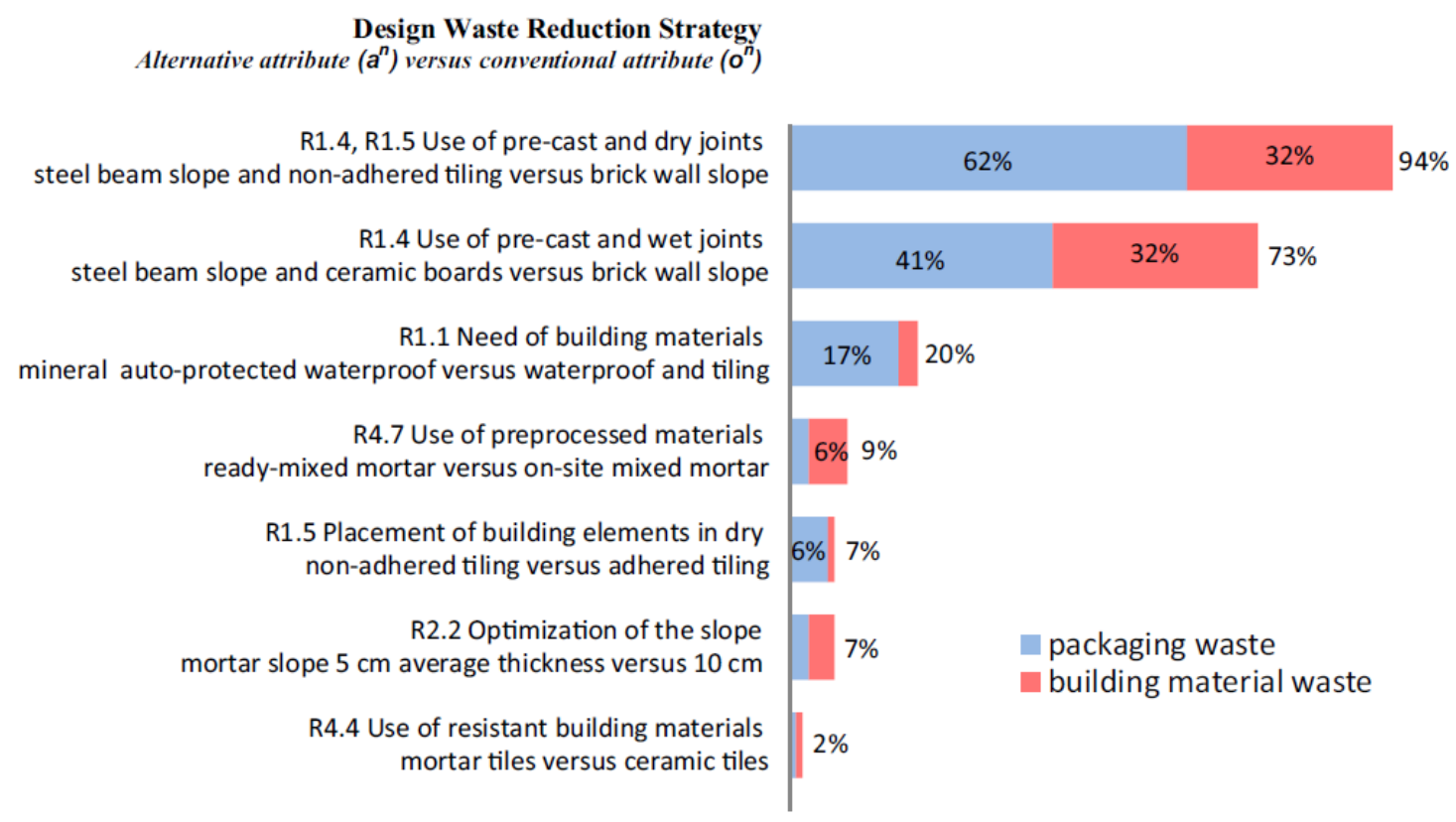

Figure 7 Achieved waste reduction levels in Roofing Building System (O6)

In the Finishing Building System (Figures 8 to 10), the most effective strategies were those that use building elements uncoated and unpainted. (100\% reduction); only painted (86$98 \%)$ or coated without the need of painting $(70 \%)$. Others, such as the use of mechanical anchorage systems instead of mortar would entail a 35\% DW reduction.

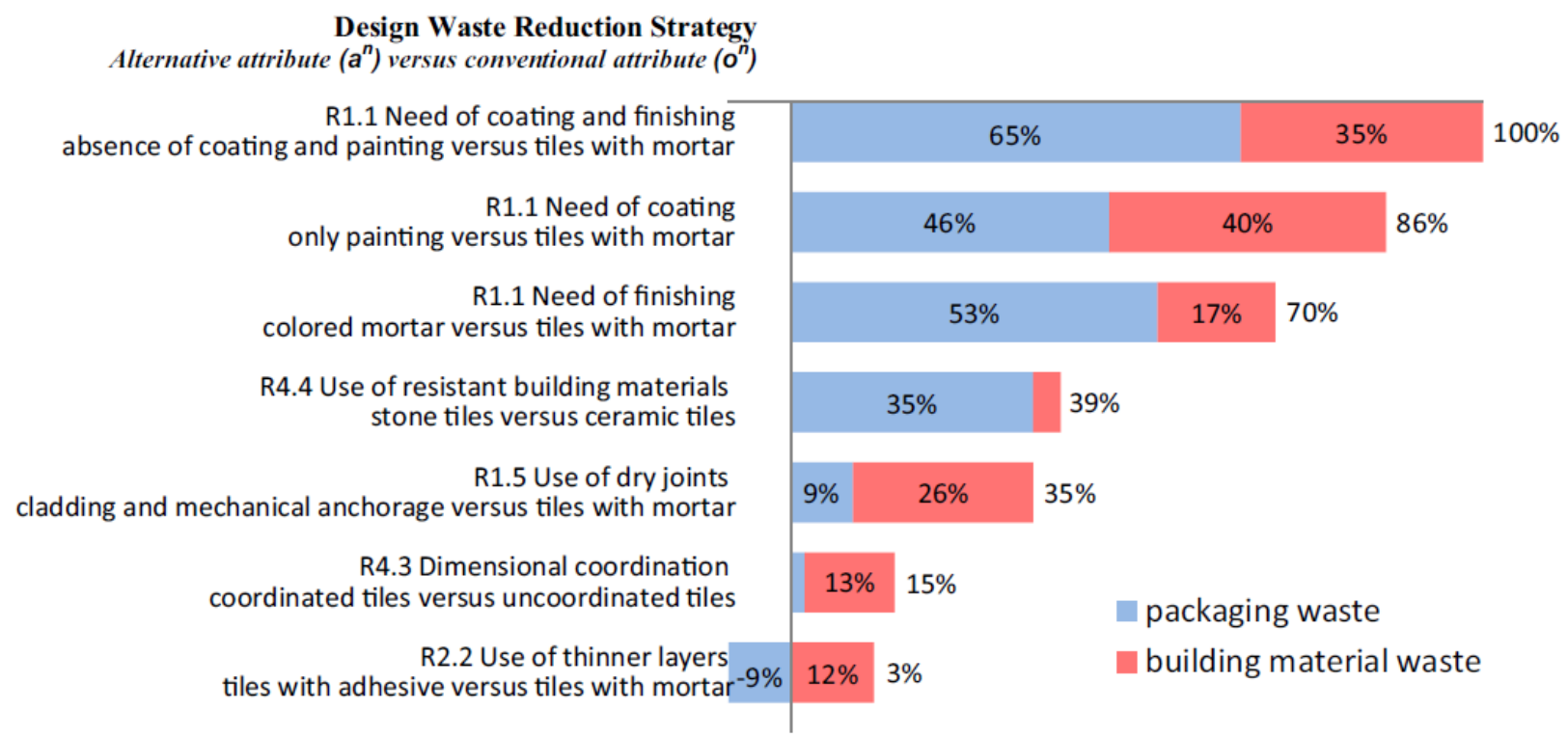

Figure 8 Achieved waste reduction levels in Finishing Building System, wall finishes (O7) 
Design Waste Reduction Strategy
Alternative attribute $\left(a^{n}\right)$ versus conventional attribute $\left(0^{n}\right)$

R1.1 Need of coating only painting with epoxy coating finish versus tiles with mortar

R2.2 Use of thinner layers carpet finish with adhesive versus tiles with mortar

R4.7 Use of preprocessed materials tiles with ready-mixed mortar versus with on-site mortar

R4.3 Dimensional coordination coordinated tiles versus uncoordinated tiles

R2.4 Avoidance of breakages uninterrupted tiles -partitions versus interrupted

R4.4 Use of materials with less breakages terrazzo tiles versus ceramic tiles

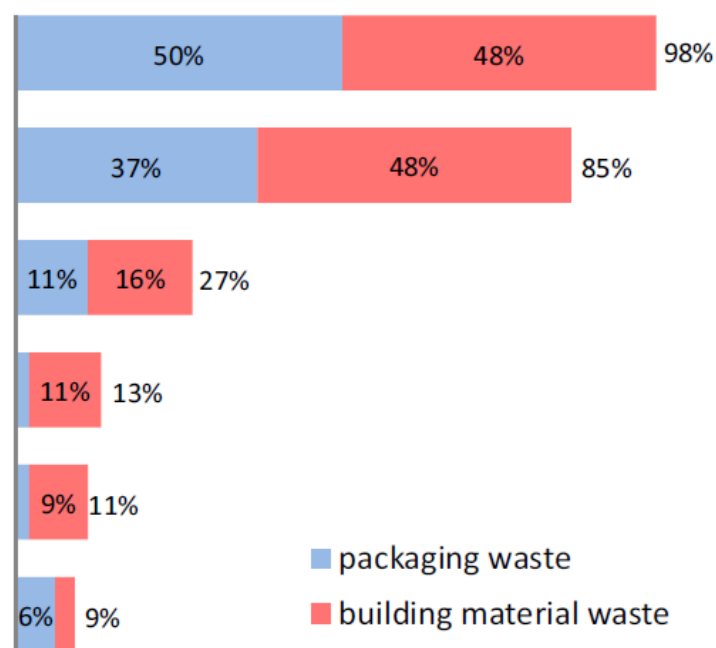

Figure 9 Achieved waste reduction levels in Finishing Building System, floor finishes (O8)

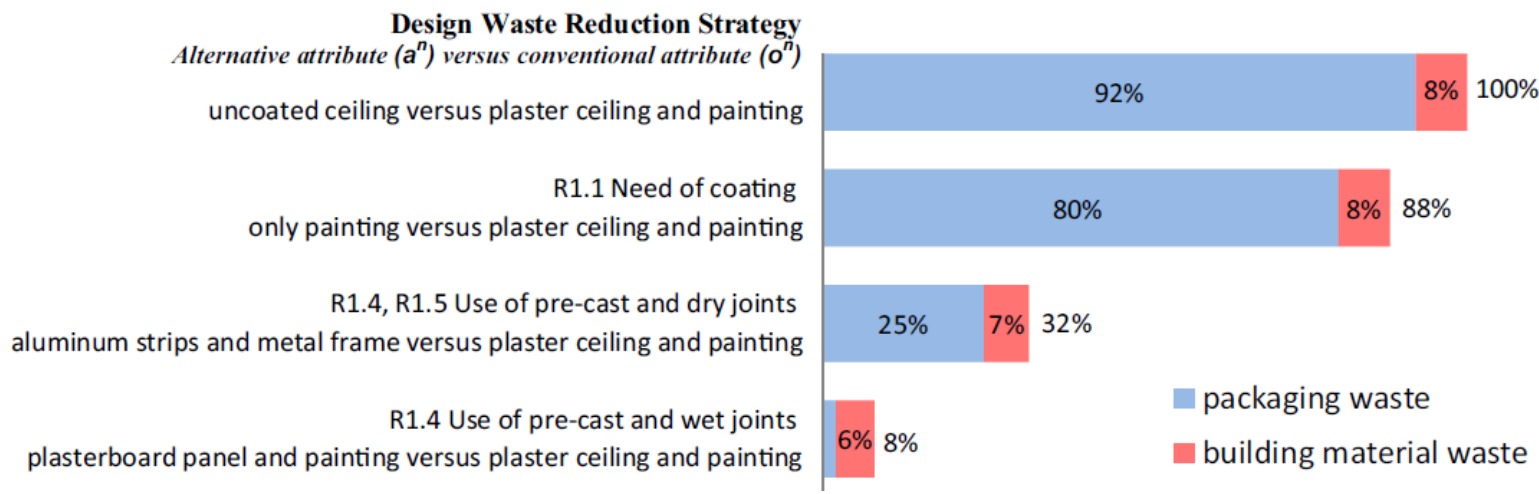

Figure 10 Achieved waste reduction levels in Finishing Building System, ceiling finishes (O9)

The major findings of this stage of the model validation process were:

- Nine DW strategy clusters were developed in relation to each building sub-system that resulted in an average of five to six strategies per cluster. The main types of waste affected by the strategies were grouped in Figures 3 to 10 to simplify data.

- While strategies vary from one building sub-system to another, the use of pre-cast and dry joints was the most effective strategy in almost all systems reaching up to $100 \%$ DW 
reduction in columns and beams; $90 \%$ in floors; $97 \%$ in walls; and $94 \%$ in roofs. The use of pre-cast and wet joints would achieve DW reduction levels ranging from $73 \%$ to $96 \%$;

- The most effective finishing building system strategies were: the use of uncoated and unpainted building elements, which would reduce up to $100 \%$ waste; the use of uncoated building elements (only painted) resulting in $86 \%$ to $98 \%$ DW reduction levels; and the use of unpainted building elements (only coated), which would reduce waste by up to $70 \%$;

- With respect to the foundation building system, the reuse of soil would achieve excavation waste reduction by up to $96 \%$. The use of pre-cast piles would reach up to $78 \%$ reduction and optimization of the excavation by halving its depth or the foundations by using slabs would lead to $42 \%$ and $24 \%$ DW reduction respectively. The use of recoverable formwork instead of brick formwork would achieve a 9-7\% reduction of soil waste. As far as hazardous waste is concerned, the use of release agents in-situ cast without organic solvent instead of release agents with organic solvent could remove $100 \%$ of hazardous waste in structural building systems due to contaminated formworks and release agent packaging. Additionally, the use of pre-cast concrete elements as well as reducing waste would further contribute to hazardous waste minimization.

- The avoidance of design changes that result in partial demolitions would be the most effective strategy in interior wall sub-system attaining $352 \%$ less waste.

- Other strategies and their respective DW waste reduction that emanated from the model validation were: masonry wooden pallet recovery (68\%); the use of blocks instead of bricks for walls (58\%); use of metal instead of wooden for column formwork (27\%); the use of ready-mixed concrete instead of in-situ concrete for columns and beams (21\%); dimensional coordination for tiles (13\%), brick walls (11\%) and flooring (11\%); and the use of pre-mixed mortar in masonry instead of in-situ mortar (5\%).

\section{Discussion}

\subsection{Validation}

The results were compared with data from other research studies to test the quantitative analysis of the model validation. A major comparison difficulty lies in the fact that the literature 
identifies broad design waste reduction strategies, as there is limited data on waste reduction levels that are specific to each building system, except for prefabrication which provides data for the entire building (Jaillon et al., 2008, Tam et al., 2007b). Another drawback is that waste reduction obtained from other investigations refers to the waste weight, while the Waste ReSt model provides reductions in volume. That said, this approximation allowed the verification of the strategies developed in this research as well as reducing levels of waste were in line with those of other investigations. As such, the use of prefabrication techniques for the entire building achieved an overall wastage reduction range from $84.7 \%$ (Tam et al. 2007a) to $100 \%$ (Tam et al., 2007b) for the entire building. Furthermore, the use of prefabricated elements would imply coordination between elements. The Waste ReSt model obtained different waste reduction rates depending on the level of prefabrication of the components. These vary between $100 \%$ in the case of dry joints and $73-96 \%$ in wet joints. However; the data obtained from this research resulted in reduction of waste emanating from the main building systems, which are absent from the literature.

Other authors identified modulation of the project and dimensional coordination (Coventry and Guthrie, 1998) as a key waste reduction strategy. The Waste ReSt model went further by revealing that dimensional coordination in floor tiles, wall tiles and brick walls would potentially reduce DW by $24 \%, 15 \%$, and $11 \%$ respectively. Greenwood (2003) reported that optimization of material resources would generate less waste. This was specifically quantified by the findings of Waste ReSt model validation case study. For example, the effects of including a $10 \mathrm{~cm}$ thick inner tube within a $24 \mathrm{~cm}$ brick wall resulted in $30 \%$ reduction of brick wastes. Equally, the design of a $10 \mathrm{~cm}$ deep roof slope achieved a 7\% waste reduction with a lower slope of $5 \mathrm{~cm}$. The impact of thinner layers in finishes on waste reduction was also assessed in the Waste ReSt model validation process. Indeed, the plastered walls and ceilings alternatives during the finishing stages, led to significant waste reduction rates ranging from 70 to $100 \%$.

Several authors have also identified design changes leading to partial demolitions as a major waste source (Poon et al., 2004; Coventry et al., 2001). A specific contribution to knowledge of this research relates to proposed DW strategies to address design changes to partitions that led to a $352 \%$ waste reduction level. The use of reclaimed building materials, as other studies have shown (Coventry and Guthrie, 1998; Kartam et al., 2004) was also assessed 
in this research. For example, the use of recoverable blocks inter-joist instead of unrecoverable blocks in the execution of cast in situ beams and pot floors allowed $21 \%$ waste reduction. Additionally, the use of recoverable formworks instead of brick formworks reduced packaging, brick, and mortar spills waste by $9 \%$. Furthermore, the recovery of masonry wooden pallets enabled timber waste reduction by $68 \%$. Other DW strategies were also evaluated that include: the use of durable materials (e.g. ceramic blocks inter-joist versus concrete blocks; terrazzo tiles versus ceramic tiles); the use of pre-processed building materials (e.g. pre-mixed mortar versus in-situ mortar); and types of building finishes (e.g. non-adhered versus adhered tiles in roofs and pavings).

This paper demonstrates that the Waste ReSt model could significantly facilitate and support designing out waste strategies that would enable the prediction of DW sources for building elements, and inform appropriate DW strategies that would result in substantial DW reduction levels. The Waste ReSt model could potentially be adopted as an integrated designing out waste platform for building projects.

\subsection{Limitations}

The limitations of this research related to data collection and model validation are presented below.

- Data collection: the research focused on residential buildings with low to medium-rise height in the area of Andalusia in Spain. Future research studies could apply the model to: other building heights (e.g. high-rise); different building types (e.g. office buildings); and other construction methods (e.g. offsite construction).

- Model validation: the lack of actual data recorded by contractors limits the validation of these types of models. However, the evidences supporting that the Waste ReSt model could be a valid approach to design out waste, are:

o Waste estimation was carried out with a quantification method already validated to predict wastes by building elements (Llatas, 2011). The absence of design waste reduction quantitative data related to each building element in the 
literature limited the comparison. Greater knowledge of the actual data of wastes in the construction industry in the future will allow the verification of the model in additional case studies. Additionally, the research focused on the construction stage using conventional building systems. Potential model developments could include processes (e.g. prefabricated building systems) and other phases of the building life cycle (e.g. refurbishment)

o The waste reduction levels were measured by volume, however, 'Quantification factors' could be redefined to measure wastes by weight.

o Other variables that reduce the environmental, economic and social impact of waste (e.g. CO2 emissions, amount of resources consumed, toxicity, economic costs) could be included and assessed,

o New strategies can be incorporated (e.g. the use of reclaimed/recycled building materials or the. reuse/recycling of the waste generated in constructive solutions). This would allow further research on reclaimed material input and reclaimed material output.

\subsection{Implications}

The major implications of this study are noted below.

- Greater informed knowledge and awareness of design waste causes and sources and associated design strategies to reduce onsite waste, which is absent from the literature. This research demonstrated this knowledge gap through the identification of 'DW Factors' and corresponding 'DW Parameters', as summarized in Table 5, which enable DW estimation. As such, a novel DW source-effect approach has been introduced in this research via the developed Waste ReST model that would facilitate design waste source traceability and assessment. This will enable construction project stakeholders, particularly, designers and constructors, to make informed design and buildability decisions to specify and select low waste strategies and systems.

- The research developed DW strategies based on a systematic and consequential stages to address the identified DW sources by devising alternative building elements that exhibit higher waste reduction attributes. These would assist architects, structural 
engineers and project managers to embed such strategies within their architectural, structural and constructions systems.

- It is well established in the literature that there is a lack of integrated design waste tools that consider all design variables and construction requirements. The Waste ReSt model could be integrated within BIM platforms to support architects, engineers and quantity surveyors to design out waste from the project outset.

- Although DW reduction strategies depend on the type construction systems and materials, the model validation process and the resulting recommendations for alternative low waste systems and materials yield significant waste reduction levels, reaching $100 \%$ in some cases. Therefore, the research findings could potentially have a far reaching impact in the design and construction of 'low waste buildings' that are focused on rationalizing the use of materials, which would inevitably result in financial gains associated with labour, transportation and disposal costs of onsite waste in construction projects.

\section{Conclusions}

There is a consensus in the literature that an informed building design would have a major impact on waste reduction at source. However; there is a lack of quantitative and holistic approaches that closely correlate waste stream generation to the employed design strategies for building systems and elements. Therefore, this research addressed this knowledge gap through the design and validation of the Waste ReSt model. The validation case study showed that greater insights into waste sources enable the development of design strategies that could contribute to up to $100 \%$ of construction waste and their toxicity.

The Waste ReSt model could trigger waste reduction instruments through the elaboration of collaborative building elements databases and design strategies that yield significant waste reduction levels in building systems. Equally, project stakeholders, particularly clients, developers, designers and contractors could implement best practice for waste reduction at source in general and building systems in particular. This could in turn contribute to a 
quantifiable improvement in the current ability to curb the rapid and significant pace of the levels of construction waste generation.

Future studies could be directed at investigating the effects of design strategies on the reduction of construction waste throughout the building lifecycle stages. Furthermore, more case studies are required to apply the Waste ReSt model in real-world situations and make appropriate methodological and validation adjustments that consider the context and the design and construction characteristics of each project.

\section{Acknowledgements}

The authors are grateful to the Consejería de Vivienda y Ordenación del Territorio de la Junta de Andalucía (Department of Housing and Regional Planning of the Andalusian Government) for subsiding the Research Project "-CDWs = + ECO-efficiency. Waste Reduction in the Design and Construction of Dwellings in Andalusia" (Andalusian Government, 2009). The authors are also grateful for the help and support from companies and individuals during the validation case study. 


\section{References}

Andalusian Government, 2009. Department of Housing and Regional Planning of the Government of Andalusia. Grants for research on Housing and Architecture. 2009 Grant Call. Spain.< http://www.juntadeandalucia.es /fomentoyvivienda /portal-web /web /areas /vivienda /texto /f27d07e8-7aba-11df-8e25-00163e67c14a> (visited 28/5/2015; currently only in Spanish).

Andalusian Government, 2015. BCCA (Base de Costes de la Construcción de Andalucía. Consejería de Vivienda y Ordenación del Territorio de la Junta de Andalucía, Seville, Spain. Available from: <http://www.juntadeandalucia.es > (last viewed may 2015; currently only in Spanish).

Baldwin, A., Poon, C., Shen, L., Austin, A., Wong, I., 2006. Designing out waste in high-rise residential buildings: analysis of precasting and prefabrication methods and traditional construction. In: Runming Y, Baizhan L, Stammers K. (Eds.), International Conference on Asia European Sustainable Urban Development, Chongqing, China, Centre for SinoEuropean Sustainable Building Design and Construction, Biejing.

Bossink, B.A.G., Brouwers, H.J.H., 1996. Construction waste: quantification and source evaluation. Journal of Construction Engineering and Management ASCE 122 (1), 55-60.

BRE - Building Research Establishment,2007. SMARTStart, BRE, Watford.

Chandrakanthi, M., Hettiaratchi, P., Prado, B., Ruwanpura, J., 2002. Optimization of the waste management for construction projects using simulation. In: Proceedings of the 2002 Winter Simulation Conference, December 8-11, San Diego, California, 1771-1777.

Cheng, J.C.P., Won, J. and Das, M. Construction and demolition waste management using BIM technology. In: Proceedings of the 23rd Ann. Conf. of the Int'l. Group for Lean Construction. Perth, Australia, 29-31 July, 2015.

Coventry, S., Guthrie, P., 1998. Waste Minimization and Recycling in Construction: Design Manual. In: CIRIA SP134. Construction Industry Research and Information Association (CIRIA), London, United Kingdom.

Coventry, S., Shorter, B., Kingsley, M., 2001. Demonstrating Waste Minimization Benefits in Construction. In: CIRIA C536. Construction Industry Research and Information Association (CIRIA), London, United Kingdom. 
Dainty, A.R.J., Brooke, R.J., 2004. Towards improved construction waste minimization: improved supply chain integration. Structural Survey. 22 (1), 20-29.

Defra (Department for Environment, Food and Rural Affairs), 2007. Waste Strategy for England 2007. The Stationery Office, London, UK.

Ekanayake, L.L., Ofori, G., 2000. Construction material waste source evaluation. In: Proceedings of the Second Southern African Conference on Sustainable Development in the Built Environment: Strategies for a Sustainable Built Environment, Pretoria, 23-25 August.

Ekanayake L.L., Ofori, G., 2004. Building waste assessment score: design-based tool. Build. Environ. 39,: 851-861.

European Commission, 2011. CDW: Material recovery \& backfilling (2011). < http://ec.europa.eu /environment /waste /studies /pdf/CDW\%20Statistics\%202011.pdf> (visited 28/5/2015).

European Commission, 2014, amending Decision 2000/532/EC on the list of waste pursuant to Directive 2008/98/EC of the European Parliament and of the Council. Official Journal of the European Union L370/ 0044-0086

European Commission, 2008 - Directive 2008/98/CE of the European Parliament and of the Council of 19 November 2008 on waste and repealing certain Directives. Official Journal of the European Union L312/,0003-0030.

Eurostat, 2010. European Commission. Environmental statistics and accounts in Europe, 2010 edition. <http://epp.eurostat.ec.europa.eu/cache/ITY_OFFPUB/KS-32-10-283/EN/KS-32-10283-EN.PDF> (visited 28/5/2015).

Eurostat, 2013. European Communities. Energy, transport and environment indicators, 2013 edition.<http://epp.eurostat.ec.europa.eu/cache/ITY_OFFPUB/KS-DK-13-001/EN/KS-DK-13001-EN.PDF> (visited 28/5/2015).

Eurostat, 2015. Waste statistics, April, 2015. <http://ec.europa.eu/eurostat/statisticsexplained/index.php/Waste_statistics> (visited 28/5/2015).

Forsythe, P., Marsden, P.K., 1999. Modelling construction waste performance an arising procurement issue. In: Ogunlana SO, editor. Profitable partnering in construction procurement. London: Spon, p. 679-688. 
Gibb, A., 2001. Standardization and Customization in Construction: A Review of Recent and Current Industry and Research Initiatives on Standardization and Customization in Construction. CRISP, London, United Kingdom.

Greenwood, R., 2003. Construction Waste Minimization - Good Practice Guide. CRiBE (Centre for Research in the Build Environment). Cardiff, United Kingdom.

Hylands, K., 2004. Designing waste out of the construction process. In: Proceedings of Minimizing Construction Waste Conference: Developing Resource Efficiency and Waste Minimization in Design and Construction, New Civil Engineer, London, United Kingdom.

Innes, S., 2004. Developing tools for designing out waste pre-site and onsite. In: Proceedings of Minimizing Construction Waste Conference: Developing Resource Efficiency and Waste Minimization in Design and Construction, October 21, New Civil Engineer, London, United Kingdom.

Jaillon, L., Poon, C.S., Chiang, Y.H., 2008. Quantifying the waste reduction potential of using prefabrication in building construction in Hong Kong. Waste Management 29, 309-320.

Kartam, N., Al-Mutairi, N., Al-Ghusain, I., Al-Humoud, J., 2004. Environmental management of construction and demolition waste in Kuwait. Waste Management 24(10), 1049-1059.

Keys, A., Baldwin, A., Austin, S., 2000. Designing to encourage waste minimisation in the construction industry. In: Proceedings of CIBSE National Conference, Dublin, Republic of Ireland.

Lawton, T., Moore, P., Cox, K., Clark, J., 2002. The gammon skanska construction system. In: Proceedings of the International Conference Advances in Building Technology Vol. 2, Hong Kong, China; 4-6 December, p. 1073-1080.

Lu, W. and Yuan, H., 2010. Exploring critical success factors for waste management in construction projects of China. Resources, Conservation and Recycling 55(2): 201-208.

Liu, Z., Osmani, M.,Demian, P., Baldwin, A.N., 2015. A BIM-aided construction waste minimisation framework. Automation in Construction 59: 1-23.Llatas, C., 2011. A model for quantifying construction waste in projects according to the European Waste List. Waste Management 31: 1261-76.

Llatas, C., 2013. Methods for estimating construction and demolition (CD) waste. In Handbook of Recycled Concrete and Demolition Waste. F. Pacheco-Torgal; J. de Brito; J Labrincha; V. 
Tam; Y. Ding. (Eds.) Woodhead Publishing Limited, Cambridge (currently Elsevier). p. 2552.

Osmani, M., Glass, J., Price, A., 2008. Architects' perspectives on construction waste reduction by design. Waste Management 28, 1147-1158.

Osmani, M., 2013. Design waste mapping: a project life cycle approach. Proceedings of the ICE-Waste and Resource Management, 166 (3), 114-127..

Pinto, T.P., Agopyan, V., 1994. Construction waste as row materials for low-cost construction products. In: Kibert CJ, editor. Proceedings of the First Conference of CIB TG 16 on Sustainable construction, Tampa, FL, USA, p. 335-342.

Poon, C.S., Jaillon, L., 2002. A Guide for Minimizing Construction and Demolition Waste at the Design Stage. The Hong Kong Polytechnic University. Hong Kong.

Poon, C.S., Yu, A.T.W., Jaillon, L., 2004. Reducing building waste at construction sites in Hong Kong. Construct. Manage. Econom. 22 (5), 461-470.

Serpell, A., Labra, M., 2003. A study on construction waste in Chile. In: Ofori G, Ling FYY, editors. Proceedings, Joint Symposium of CIB W55, W65 and W107 on Knowledge Construction vol. 2, Singapore, p. 102-111.

Skoyles, E.R., Skoyles, J.R., 1987. Waste prevention on site. London: Mitchell.

Spanish Government - Ministry of the Environment, 2009. Plan Nacional Integrado de Residuos 2007-2015 (National Integrated Waste Plan 2007-2015). Ministry of the Environment, Madrid, Spain. BOE 049 of 26/2/2009.

Spanish Government, 2015. Building construction data 2009 - 2013. Ministry of Development, Madrid, Spain. Series in Statistics. http://www.fomento.gob.es/NR/rdonlyres/97E44F6E61C2-470F-B8E4-903EC04F8B6A/125816/ConstruccionEdificios2013.pdf> (visited 28/5/2015)

Tam, C.M., Tam, V.W.Y., Chan, J.K.W., Ng, W.C.Y., 2005. Use of prefabrication to minimize construction waste-a case study approach. The Int. J. Construct. Manage. 5 (1), 91-101.

Tam, V.W.Y., Shen, L.Y., Tam, C.M., 2007a. Assessing the levels of material wastage affected by sub-contracting relationships and projects types with their correlations. Build. Environ. 42 (3), 1471-1477. 
Tam, V.W.Y., Tam, C.M., Zeng, S.X., Ng, W.C.Y., 2007b. Towards adoption of prefabrication in construction. Build. Environ. 42 (10), 3642-3654.

WRAP (Waste and Resources Action Programme), 2008. Halving Waste to Landfill: Are You Committed? WRAP, Banbury, UK.

Yuan, H., Shen, L., 2011. Trend of the research on construction and demolition waste management. Waste Management 31, 670-679.

Yuan, H, Chini, AR, Lu, Y., Shen L., 2012. A dynamic model for assessing the effects of management strategies on the reduction of construction and demolition waste. Waste Management 32(3), 521-531.

Won, J., Cheng, JC., Lee, G., 2016. Quantification of construction waste prevented by BIMbased design validation: Case studies in South Korea. Waste Management. 49, 170-180.

Wu, Z., Yu, A.T.W., Shen, L., Liu, G., 2014. Quantifying construction and demolition waste: An analytical review. Waste Management. 34, 1683-1692. 